\title{
Pd-catalyzed domino dehydrogenation/Heck-type reactions of carbonyl compounds
}

Jean Le Bras and Jacques Muzart*

Institut de Chimie Moléculaire de Reims, UMR 7312, CNRS - Université de Reims

Champagne-Ardenne, B.P. 1039, 51687 Reims Cedex 2, France

e-mail: jacques.muzart@univ-reims.fr

www.univ-reims.fr/icmr

Abstract. This review covers the domino reactions which involve, at least, both Pd-catalyzed dehydrogenation of carbonyl compounds and Heck-type reactions. While the former occurs under $\mathrm{Pd}^{\mathrm{II}}$-catalysis, $\mathrm{Pd}^{0}$ - or $\mathrm{Pd}^{\mathrm{II}}$ catalyst is requested for the latter, depending on the nature of the (hetero)arylating agent, $\mathrm{ArX}$ or $\mathrm{ArH}$, respectively. The regeneration of $\mathrm{Pd}^{\mathrm{II}}$ species is assumed by either an oxidant or the aryl halide. Proposed mechanisms are described, with, in some cases, personal comments.

Contents.

1. Introduction

2. Domino KTR $+\mathrm{HR}(\mathrm{s})$

3. Domino KTR + OHR

4. Domino KTR + DcHR

5. Domino KTR + DHR

6. Domino KTR + PHR

6.1 Using aryl halides

6.2 Using arenes

7. Domino OHR $+\mathrm{KTR}+\mathrm{PHR}$

8. Domino HR $+\mathrm{KTR}+\mathrm{HR}$

9. Domino KTR + ketonisation + DHR

10. Domino $\mathrm{C}\left(\mathrm{sp}^{3}\right)-\mathrm{H}$ arylation $+\mathrm{KTR}+\mathrm{HR}(+\mathrm{DHR})$

11. Domino $\mathrm{C}\left(\mathrm{sp}^{3}\right)-\mathrm{H}$ arylation $+\mathrm{KTR}($ or $\mathrm{KTR}+\mathrm{HR})+\mathrm{HR}+\mathrm{C}\left(\mathrm{sp}^{2}\right)-\mathrm{H}$ amidation

12. Conclusion

13. References

\section{Introduction}

The synthesis of complex organic molecules via a one-pot reaction corresponds to the sequential addition of the reactants to the reaction flask, possibly under experimental conditions depending of each reactant, followed by work-up and purification. ${ }^{[1]}$ This procedure is more compatible with economic and ecological constraints than the step by step synthesis, which is time-consuming, requires extraction and purification steps leading to large amounts of waste. 
The most attractive procedure is however the domino reaction which, according to Tietze, leads to the formation of "several bonds in one sequence without isolating the intermediates, changing the reaction conditions, or adding reagents". ${ }^{[2.3]}$ According to Fogg and dos Santos, ${ }^{[4]}$ the appellation "tandem" could be attributed to some of these reactions but Tietze suggested not to use it, because "Tandem means two at the same time and does not describe a time-resolved transformation". ${ }^{[5]}$ The aim of the present review is to highlight domino reactions which implicate two Pd-catalyzed reactions: dehydrogenation of a carbonyl compound and Heck-type reaction. ${ }^{[6]} \mathrm{Pd}$ catalyst being used in both reactions, the term "auto-tandem catalysis" has been proposed for such one-pot processes ${ }^{[4.7]}$ but as Tietze, ${ }^{[5]}$ we are not fond of it. The definition of the domino reaction ${ }^{[2]}$ leads to discard procedures involving a modification of the starting conditions in the course of the process. ${ }^{[8]}$

$\alpha, \beta$-Unsaturated carbonyl compounds are highly useful synthetic blocks in organic synthesis, which can be prepared from $\mathrm{Pd}^{\mathrm{II}}$-catalyzed dehydrogenation of the corresponding saturated substrates as depicted in Scheme 1. ${ }^{[6 a, 9]}$ Sometimes, this reaction (noted below KTR), which has been discovered by Kirschke and Theisen, ${ }^{[10-12]}$ is improperly named the Saegusa's reaction. Indeed, Saegusa's reaction ${ }^{[13]}$ concerns the oxidation of silyl enol ethers and related enol derivatives to $\alpha, \beta$-unsaturated carbonyl compounds. ${ }^{[14]}$ Over-dehydrogenation of cyclohexanones may afford the corresponding phenols. ${ }^{[6 a, 9,12,15]}$

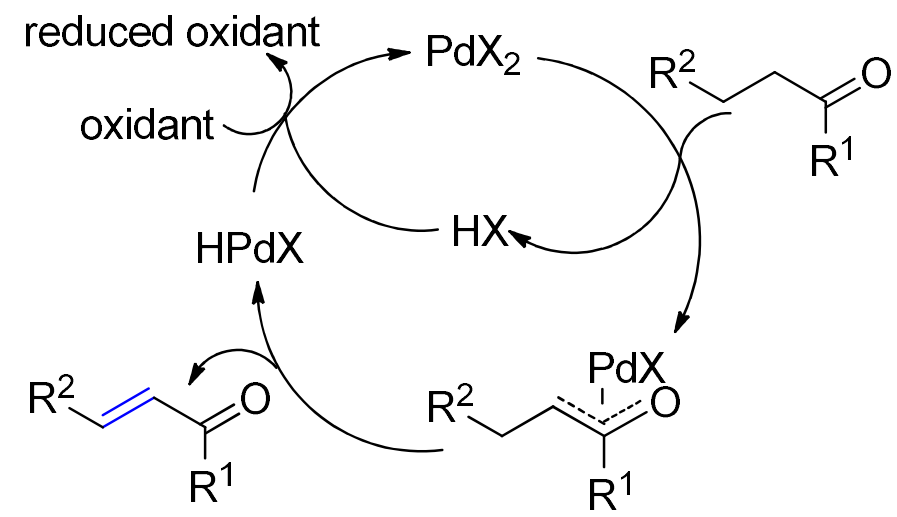

Scheme 1. Pd ${ }^{\mathrm{II}}$-catalyzed dehydrogenation of carbonyl compounds (KTR).

Heck-type reactions are involved in a number of domino reactions leading to multiple $\mathrm{C}-\mathrm{C}$ or C-heteroatom bonds. ${ }^{[16,17]}$ Originally, the Heck reaction (HR), independently discovered by the teams of Mizoroki, ${ }^{[18]} \mathrm{Julia}^{[19]}$ and Heck, ${ }^{[20]}$ is the formation of arylalkene from the $\mathrm{Pd}^{0}$ catalyzed coupling of an aryl halide with an alkene (Scheme 1, path $a$ ). When a $\mathrm{Pd}^{\mathrm{II}}$ salt is used as the starting catalyst, its in-situ reduction under the experimental conditions affords the required $\mathrm{Pd}^{0}$ species. ${ }^{[18,20]}$ Heck's team, which intensively worked in this research area, also discovered the synthesis of arylalkenes via trans-metalation with $\mathrm{Pd}^{\mathrm{II}}$ catalysts of organometallic reagents used as the aryl source (Scheme 1, path $b$ ) $;^{[21]}$ such procedure is often called oxidative Heck reaction (OHR). ${ }^{[22]}$ Myers'team proposed the decarboxylative Heck reaction (DcHR), which uses arene carboxylates to form such $\mathrm{C}\left(\mathrm{sp}^{2}\right)-\mathrm{C}\left(\mathrm{sp}^{2}\right)$ bonds (Scheme 1, path $c) .{ }^{[23]}$ Another procedure, initiated by Fujiwara's team, ${ }^{[24]}$ is the dehydrogenative Heck reaction (DHR), which involves $\mathrm{Pd}^{\mathrm{II}}$-catalyzed activation of an arene $\mathrm{C}-\mathrm{H}$ bond (Scheme 1 , path d). ${ }^{[25]}$ Intermediate $\mathbf{2 A}$ may suffer either reductive Heck reaction $(\mathrm{RHR})^{[26,27]}$ or 
protonolysis (PHR) ${ }^{[27-29]}$ rather than $\beta$-H elimination to afford the arylalkyl (Scheme 1, paths $e$ and $f$, respectively. Heck-type reactions also occur using alkenyl halides instead of aryl halides. $^{[16,20]}$

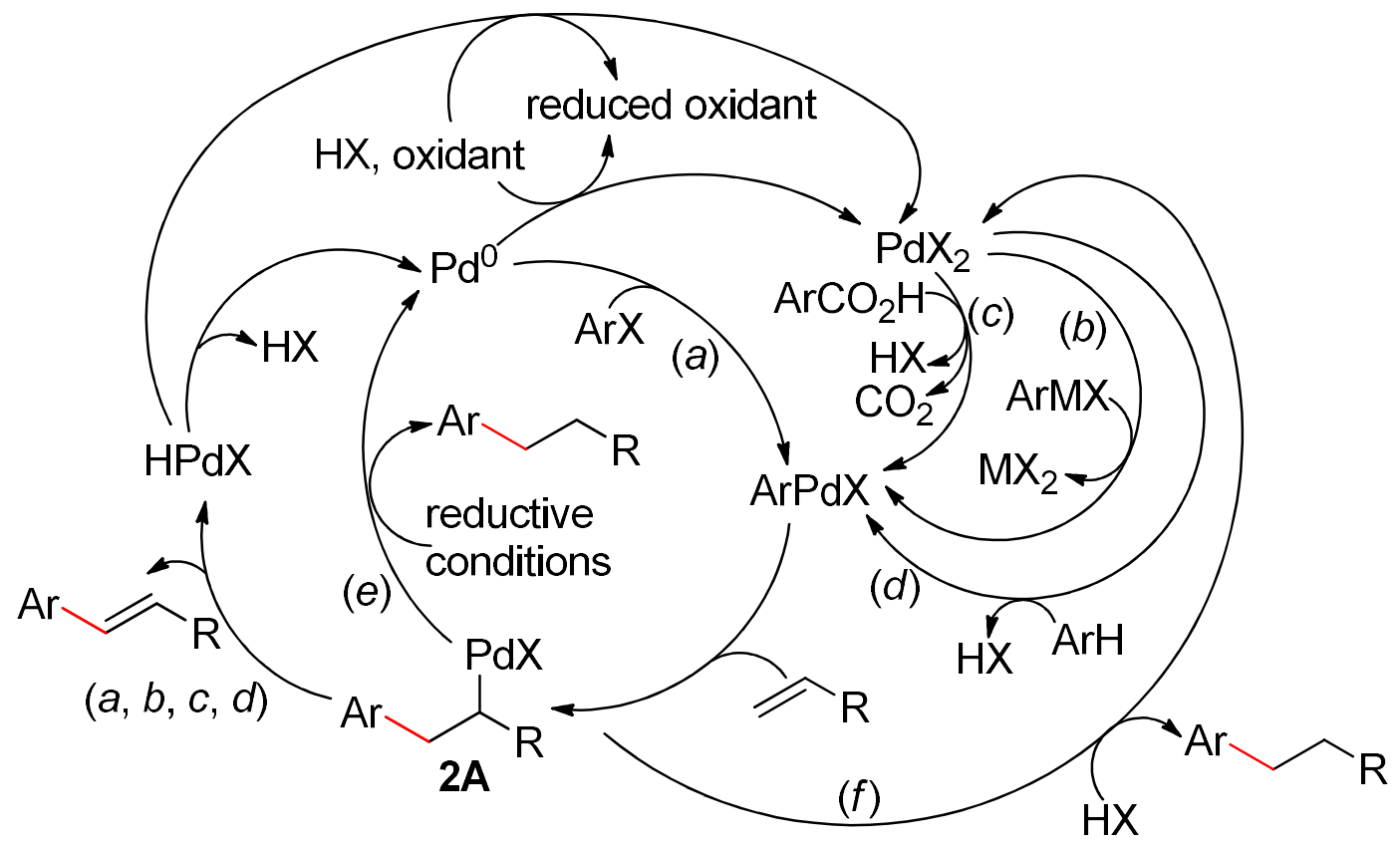

Scheme 2. Some Heck-type reactions: HR (path $a$ ), OHR (path $b$ ), DcHR (path $c$ ), DHR (path d), RHR (path $e$ ), PHR (path $f$ ).

\section{Domino KTR + HR(s)}

A number of KTR-HR(s) of aldehydes, ketones and esters have been carried out by Cheng's team using $\mathrm{Pd}(\mathrm{OAc})_{2}$ as catalyst, $\mathrm{Na}_{2} \mathrm{CO}_{3}$ as the base and an excess of aryl iodides at $120{ }^{\circ} \mathrm{C}$ in DMSO under nitrogen. ${ }^{[30]}$ The excess of ArI regenerates $\mathrm{Pd}^{\mathrm{II}}$ species from $\mathrm{Pd}^{0}$, as that occurs for Yoshida's Pd ${ }^{\mathrm{II}}$-catalyzed oxidation procedure of alcohols. ${ }^{[31]}$ 2-Phenylpropanal and $\alpha$-substituted propiophenones reacted with a variety of aryl iodides ( 2.5 equiv.) leading efficiently to the corresponding $\beta$-arylated $\alpha, \beta$-unsaturated aldehydes and ketones [Eqs (1) and (2)]. In contrast to the $\alpha$-substituted propiophenones [Eq. (2)], the reaction of propiophenone afforded mainly the $\beta$-diarylation product. Such compounds were then synthetized using a large excess of ArI [Eq. (3)]. However, butyraldehyde, pentan-2-one and 1-phenylbutan-1-one, which have a $\beta$-methyl substituent, did not give the KTR-HR products [Eq. (4)]; that is surprising because their reaction could be expected from literature data. ${ }^{[32,33]}$ To give the dehydrogenative coupling products with 2-phenylpropanal and propiophenone, aryl bromides have to react in the presence of 1,4-bis(diphenylphosphino)butane and in DMF instead of DMSO (Eq. 5). ${ }^{[30,34]}$ 
$\mathrm{Ph}_{(2.5 \text { equiv. })}^{\mathrm{Pd}(\mathrm{OAc})_{2}(0.02 \text { equiv.) }} \frac{\mathrm{Na}_{2} \mathrm{CO}_{3}(2 \text { equiv. })}{\mathrm{DMSO}_{2}, 120^{\circ} \mathrm{C}, 15 \mathrm{~h}}$

$\mathrm{R}=\mathrm{H}(87 \%), p-\mathrm{Me}(85 \%)^{\mathrm{a}, \mathrm{b}}, p-\mathrm{OMe}(76 \%), p-\mathrm{F}(72 \%), p-\mathrm{Cl}(85 \%)$, $p-\mathrm{CF}_{3}(83 \%), p-\mathrm{Ph}\left(67 \%{ }^{\mathrm{c}}\right), p-\mathrm{CO}_{2} \mathrm{Et}\left(75 \%{ }^{\mathrm{c}}\right), \mathrm{o}-\mathrm{Me}(73 \%)$

a Other solvents: DMF (32\%), AcOH (12\%), DMA (trace), PhMe (0\%) bother bases: $\mathrm{K}_{2} \mathrm{CO}_{3}(77 \%), \mathrm{Cs}_{2} \mathrm{CO}_{3}(66 \%), \mathrm{NaHCO}_{3}(71 \%), \mathrm{NaOAc}(69 \%)$ ${ }^{\mathrm{C}} \mathrm{PdCl}_{2}\left(\mathrm{PPh}_{3}\right)_{2}$ as catalyst.<smiles>[R]C(C)C(=O)c1ccccc1</smiles>

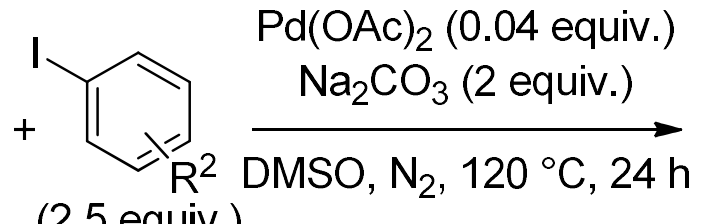<smiles>[R][X]1=C=CC=CC(C=C([R])C(=O)c2ccccc2)=C1</smiles>

(2.5 equiv.)

$\mathrm{R}^{1}=\mathrm{Ph}, \mathrm{R}^{2}=\mathrm{H}(76 \%), \mathrm{o}-\mathrm{Me}(67 \%), m-\mathrm{Me}(73 \%)$

$\mathrm{R}^{1}=\mathrm{Me}, \mathrm{R}^{2}=p-\mathrm{Me}(57 \%), p-\mathrm{MeO}(65 \%)$<smiles>[R]C(=O)CC</smiles>

$\mathrm{Pd}(\mathrm{OAc})_{2}$ (0.04 equiv.) (3.5 equiv.)<smiles>[R][R]1ccccc1C(=CC([R])=O)c1cccc([R])c1</smiles>

$\mathrm{R}^{1}=\mathrm{Ph}, \mathrm{R}^{2}=\mathrm{H}(78 \%), \mathrm{o}-\mathrm{Me}(71 \%), m-\mathrm{Me}(82 \%), p-\mathrm{Me}(91 \%)$, $m-\mathrm{MeO}(82 \%), p-\mathrm{MeO}$ (67\%), $m-\mathrm{F}$ (74\%), p-F (69\%)

$\mathrm{R}^{2}=p-\mathrm{Me}, \mathrm{R}^{1}=0-\mathrm{MeC}_{6} \mathrm{H}_{4}(84 \%), m-\mathrm{MeC}_{6} \mathrm{H}_{4}(79 \%), p-\mathrm{MeC}_{6} \mathrm{H}_{4}(86 \%)$

$\mathrm{R}^{1}=\mathrm{H}, \mathrm{R}^{2}=\mathrm{H}(77 \%), m-\mathrm{Me}(61 \%), p-\mathrm{Me}(81 \%), p-\mathrm{MeO}(82 \%)$, $p-\mathrm{Cl}(73 \%), p-\mathrm{F}(71 \%)$

$\mathrm{R}^{1}=\mathrm{Me}, \mathrm{R}^{2}=\mathrm{H}(51 \%), p-\mathrm{Me}(62 \%), p-\mathrm{MeO}(53 \%), p-\mathrm{Cl}(39 \%), p-\mathrm{F}(43 \%)$ $\mathrm{R}^{1}=\mathrm{OMe}, \mathrm{R}^{2}=\mathrm{H}(34 \%), p-\mathrm{Me}(39 \%), p-\mathrm{Cl}(32 \%)$

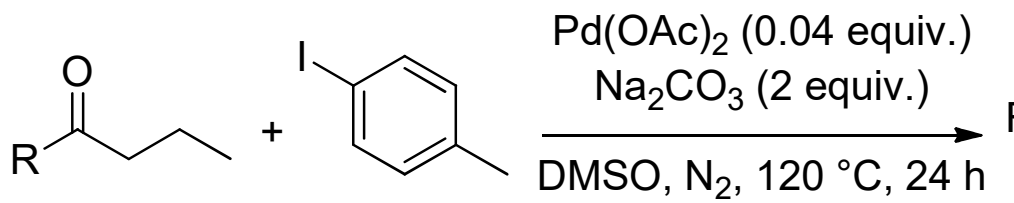<smiles>[R]C(=O)C=C(C)c1ccc(C)cc1</smiles>

(2.5 equiv.)

$\mathrm{R}=\mathrm{H}(0 \%), \mathrm{Me}(0 \%), \mathrm{Ph}(0 \%)$ 


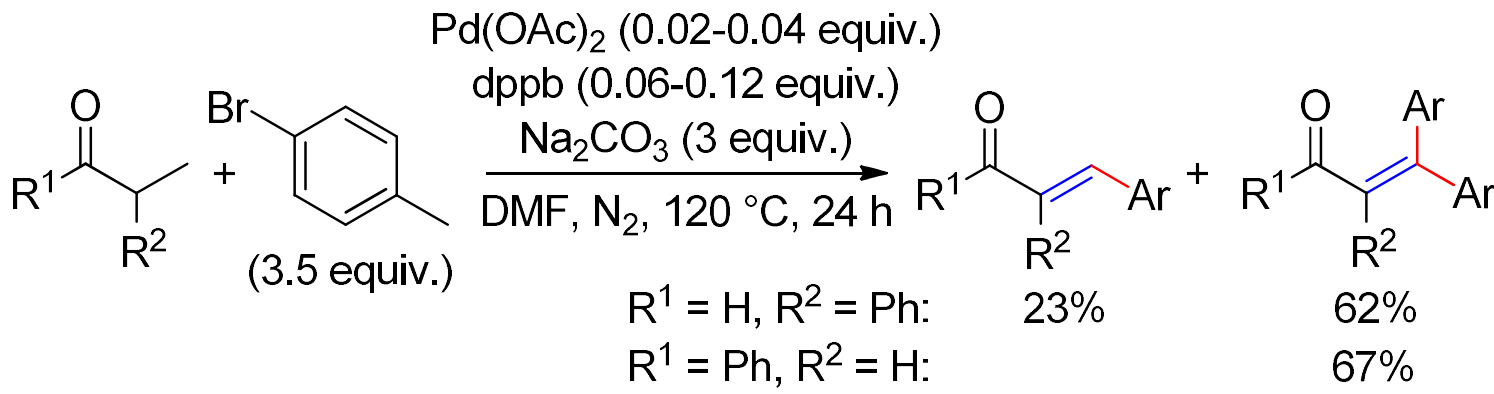

The formation of $17 \%$ of the 1,1-diarylation product against $26 \%$ of the 1,1,5,5-tetraarylation product from the reaction of diethyl ketone with 4-iodotoluene [Eq. (6)] suggested to Cheng and co-workers that "the dehydrogenation step is slower than the Heck reaction step" ${ }^{[30]}$ In fact, the same type of species, $\mathrm{ArPd}^{\mathrm{II}} \mathrm{I}$ or $\mathrm{ArPd}^{\mathrm{II}} \mathrm{I}(\mathrm{DMSO}){ }_{\mathrm{n}}{ }^{[35]}$ may mediate the KTR and the HR (Scheme 3), hence the competition between the two reactions.

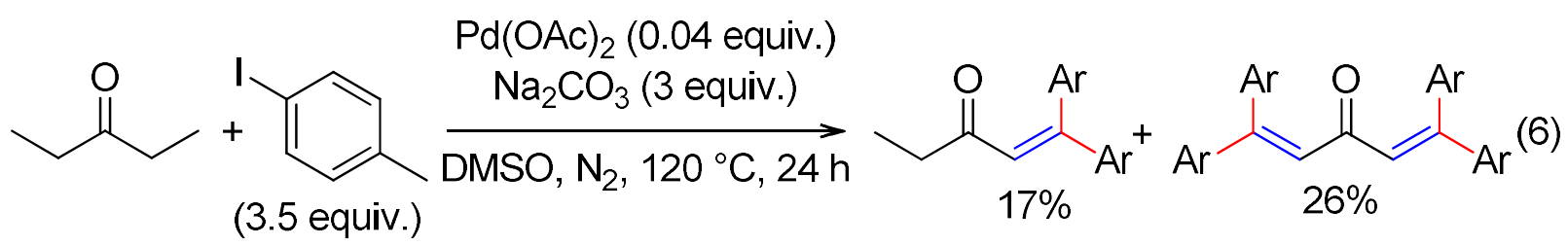

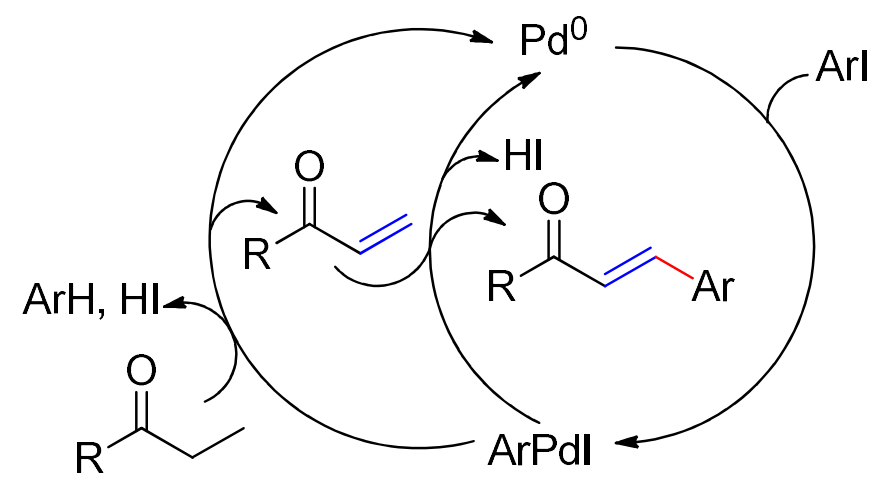

Scheme 3. The competition between KTR and HR in the domino reaction.

The optimum conditions recently reported by the team of Xie and Shao ${ }^{[36]}$ for the synthesis of $\beta$, $\beta$-diarylacroleins from arylpropanals and aryl iodides, $\mathrm{Ag}_{2} \mathrm{CO}_{3}$ as the base ${ }^{[37]}$ in $\mathrm{AcOH}$ under air [Eq. (7)], differ from those above. Given the yield decrease with either the amount of the aryl iodide or using nitrogen [Eq. (7)], we devise that both ArI and $\mathrm{O}_{2}{ }^{[38]}$ participate in the regeneration of the $\mathrm{Pd}^{\mathrm{II}}$ catalyst. The authors proposed the promotion of the HR by AgI formed in the course of the process. 
$\overbrace{}^{\text {H }}$<smiles>Ic1cc[R]cc1</smiles>

$\mathrm{Pd}(\mathrm{OAc})_{2}(0.1$ equiv. $)$

(2.5 equiv.)<smiles>[R]c1cccc(C(=CC=O)c2ccccc2[R])c1</smiles>

$\mathrm{R}^{1}=\mathrm{H}, \mathrm{R}^{2}=\mathrm{H}(78 \%)^{\mathrm{a}, \mathrm{b}, \mathrm{c}, \mathrm{d}}, \mathrm{o}-\mathrm{Me}(30 \%), m-\mathrm{Me}(67 \%), p-\mathrm{Me}(83 \%), o-\mathrm{Cl}(34 \%)$, $m-\mathrm{Cl}(52 \%), p-\mathrm{Cl}(61 \%), p-\mathrm{F}(42 \%), p-\mathrm{Br}(55 \%), p-\mathrm{OMe}(66 \%)$, $p-\mathrm{CF}_{3}(58 \%), p$-Et $(72 \%), p-(i-\mathrm{Pr})(38 \%), p-(t-\mathrm{Bu})(47 \%)$

$\mathrm{R}^{1}=p-\mathrm{Cl}, \mathrm{R}^{2}=o-\mathrm{Me}(32 \%), m-\mathrm{Me}(65 \%), p-\mathrm{Me}(71 \%), o-\mathrm{Cl}(37 \%)$, $m-\mathrm{Cl}(54 \%), p-\mathrm{Cl}(66 \%)$

$\mathrm{R}^{1}=0-\mathrm{F}, \mathrm{R}^{2}=\mathrm{H}(0 \%)$

$\mathrm{R}^{1}=m-\mathrm{F}, \mathrm{R}^{2}=\mathrm{H}(64 \%), p-\mathrm{Me}(46 \%), m-\mathrm{Cl}(48 \%), p-\mathrm{Cl}(50 \%)$

$\mathrm{R}^{1}=p-\mathrm{F}, \mathrm{R}^{2}=p-\mathrm{Me}(66 \%), m-\mathrm{Cl}(55 \%), p-\mathrm{Cl}(58 \%)$

a $55 \%$ using 1.5 equiv. of iodobenzene

$\mathrm{b}_{4} 4 \%$ under argon

'Other solvents: $\mathrm{H}_{2} \mathrm{O}(34 \%)$, DMF (0\%), PhMe (0\%)

dOther bases in DMF: $\mathrm{K}_{2} \mathrm{CO}_{3}(31 \%), \mathrm{NaHCO}_{3}(18 \%), \mathrm{NEt}_{3}(0 \%)$.

\section{Domino KTR + OHR}

Kim's team reported the synthesis of a range of 3-arylchromones from the KTR-OHR of chromanones with arylboronic acid pinacol esters. ${ }^{[39]}$ Optimum conditions arose at $100{ }^{\circ} \mathrm{C}$ in DMSO and oxygen with catalytic amounts of both $\mathrm{Pd}\left(\mathrm{OCOCF}_{3}\right)_{2}$ and 5-nitro-1,10phenanthroline [Eq. (8)]. The cross-coupling was also efficient in DMF but other solvents such as THF, dioxane, PhMe and $\mathrm{MeCN}$, or the absence of the phenanthroline ligand led mainly to the chromone (up to $72 \%$ ). Under the optimum conditions, traces of 2-arylchroman4-one, which are produced from the domino KTR-PHR, were possibly produced. Both KTR and $\mathrm{OHR}$ require $\mathrm{Pd}^{\mathrm{II}}$ catalysis. According to the authors, oxygen assumes the catalyst regeneration, ${ }^{[39]}$ but DMSO may also participate to the process. ${ }^{[40]}$

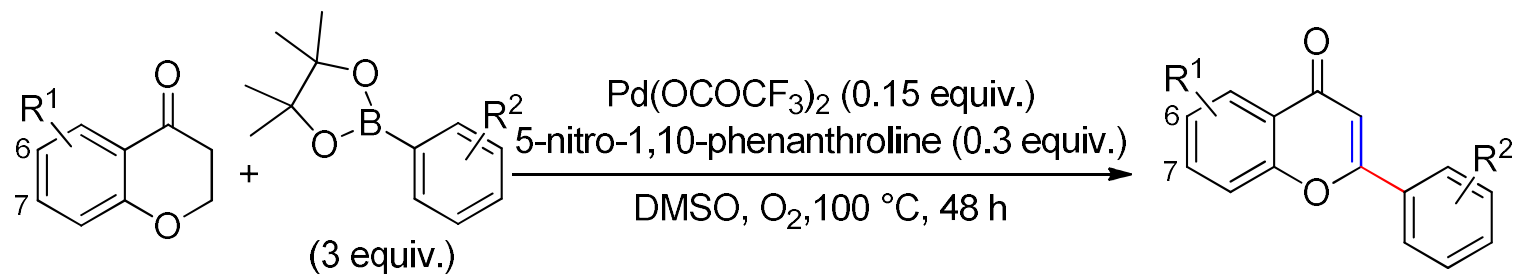

$\mathrm{R}^{1}=\mathrm{H}, \mathrm{R}^{2}=\mathrm{H}(93 \%), p-\mathrm{Me}(75 \%), p-(t-\mathrm{Bu})(81 \%), p-\mathrm{Ph}(75 \%), p-\mathrm{Cl}(60 \%), p-\mathrm{Br}(48 \%), p-\mathrm{F}(70 \%)$, $p$-TMS (90\%), p-OBz (54\%), p-- $\mathrm{CF}_{3}(27 \%), p-\mathrm{OMe}(73 \%), m-\mathrm{OMe}(79 \%), m-\mathrm{OH}(69 \%)$

$\mathrm{R}^{2}=\mathrm{H}, \mathrm{R}^{1}=6-\mathrm{NO}_{2}(51 \%), 6-\mathrm{Cl}(80 \%), 6-\mathrm{F}(79 \%), 6-\mathrm{Me}(85 \%), 6-\mathrm{OMe}(73 \%), 7-\mathrm{OMe}(82 \%)$, $7-\mathrm{OCO}-\mathrm{Bu}(51 \%)$

Rather similar conditions were used by Vilela, Lee and co-workers to carry out the KTR-OHR of substituted 1,3-cyclopentadiones. ${ }^{[41]}$ The authors however observed that, with $\mathrm{Pd}(\mathrm{OAc})_{2}$ associated to 1,10-phenanthroline in DMF under oxygen, the yields were higher using a non- 
anhydrous solvent and non-dried glassware instead of anhydrous conditions [Eq. (9)]. The authors proposed that residual water promotes the transmetalation. ${ }^{[42]}$

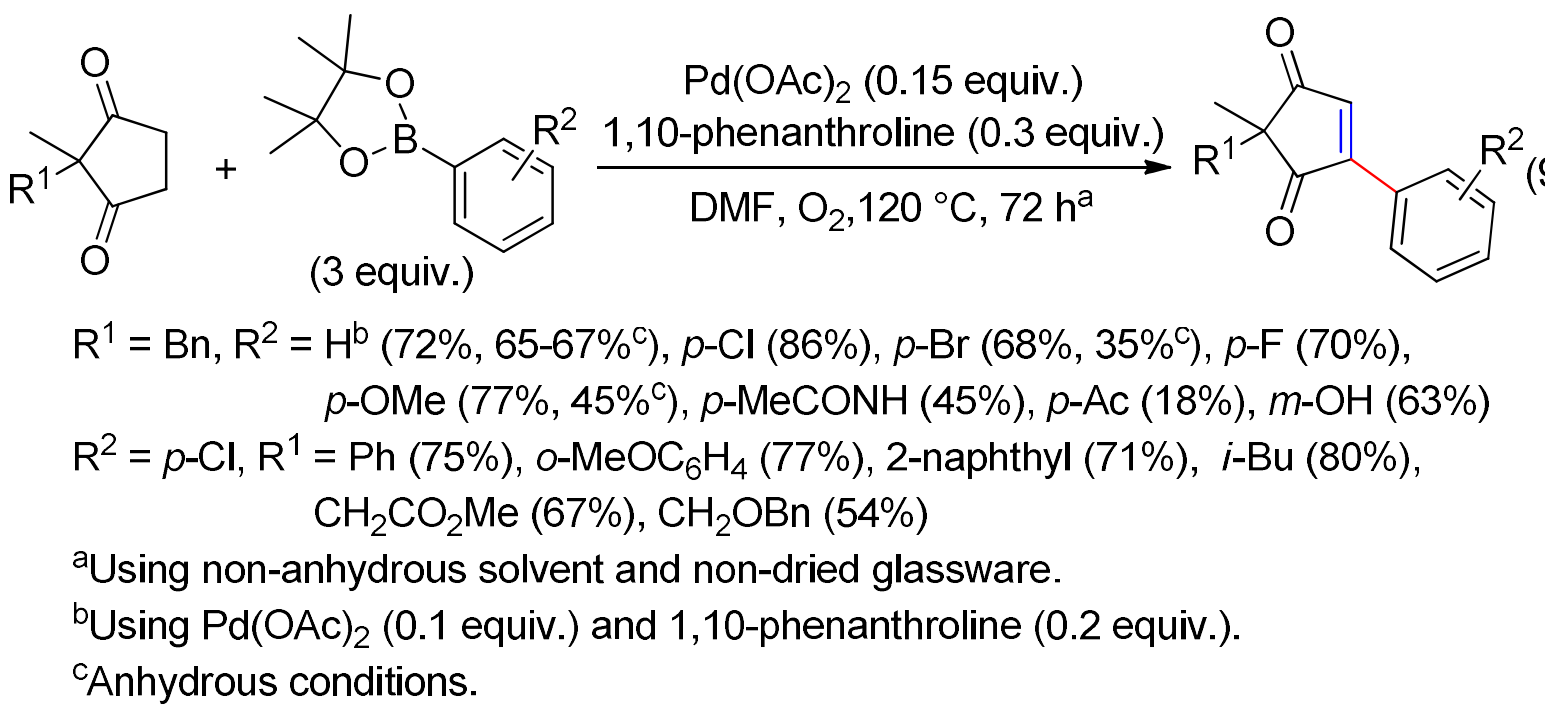

\section{Domino KTR + DcHR}

The KTR-DcHR disclosed by Su and co-workers concerns the $\mathrm{Pd}^{\mathrm{II}}$-catalyzed cross-coupling of propiophenones with aryl carboxylic acids. ${ }^{[43]}$ The efficiency of this domino reaction is very sensitive to the structure of the substrates, hence optimum experimental conditions depending on the substitution of the aryl cores. Most reported results were obtained using a mixture of $\mathrm{Pd}(\mathrm{OAc})_{2}$ and $\mathrm{PCy}_{3}$ as the catalyst, $\mathrm{Ag}_{2} \mathrm{CO}_{3}$ as the oxidant, $n$ - $\mathrm{Bu} 4 \mathrm{NOAc}$. AcOH as the base in DMF or DME [Eqs (10) to (12)]. $\mathrm{Cu}(\mathrm{OAc})_{2}$ or $\mathrm{CuF}_{2}$ can be more efficient than $\mathrm{Ag}_{2} \mathrm{CO}_{3}$ for the DcHR of electron-rich and heterocyclic carboxylic acids with 1phenylpropen-1-one [Eqs (10) and (11)]. Most substituted propiophenones leading to poor results, the authors suspected that $\alpha-\mathrm{H}$ acidity varies with the substituent on the benzene ring, and proposed that adequate acids or bases have to be used, hence the use of subquantities of phenol as additive, or the change of $n$-Bu№Ac.AcOH for KOAc [Eq. (12)]. In fact, Buchwald and co-workers disclosed that phenol promotes the Pd-catalyzed arylation of ketone enolates with $o$-halonitroarenes, and suspected its beneficial role in the formation of palladium enolates. ${ }^{[44]}$ Thus, phenol could also promote the KTR, which also occurs via a palladium enolate. ${ }^{[6 a, 9]}$

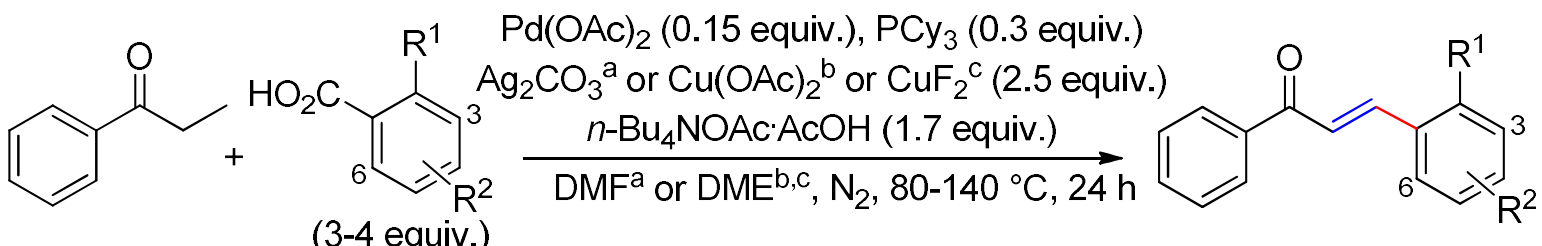

$\mathrm{R}^{1}=\mathrm{NO}_{2}, \mathrm{R}^{2}=\mathrm{H}^{\mathrm{a}}(71 \%)^{\mathrm{d}}, 4-\mathrm{Me}^{\mathrm{a}}(68 \%), 5-\mathrm{Me}^{\mathrm{a}}(61 \%), 4-\mathrm{OMe}^{\mathrm{a}}(75 \%), 5-\mathrm{OMe}^{\mathrm{a}}(56 \%), 4-\mathrm{F}^{\mathrm{b}}(31 \%)$

$\mathrm{R}^{1}=\mathrm{OMe}, \mathrm{R}^{2}=4-\mathrm{Me}^{\mathrm{c}}(75 \%), 4-\mathrm{OMe}^{\mathrm{b}}(78 \%), 6-\mathrm{OMe}^{\mathrm{b}}(62 \%)$

dOther ligands: $\mathrm{PPh}_{3}(0 \%)$, dppe $(0 \%)$, Xphos $(0 \%), \mathrm{P}(t-\mathrm{Bu})_{3}(0 \%)$ 

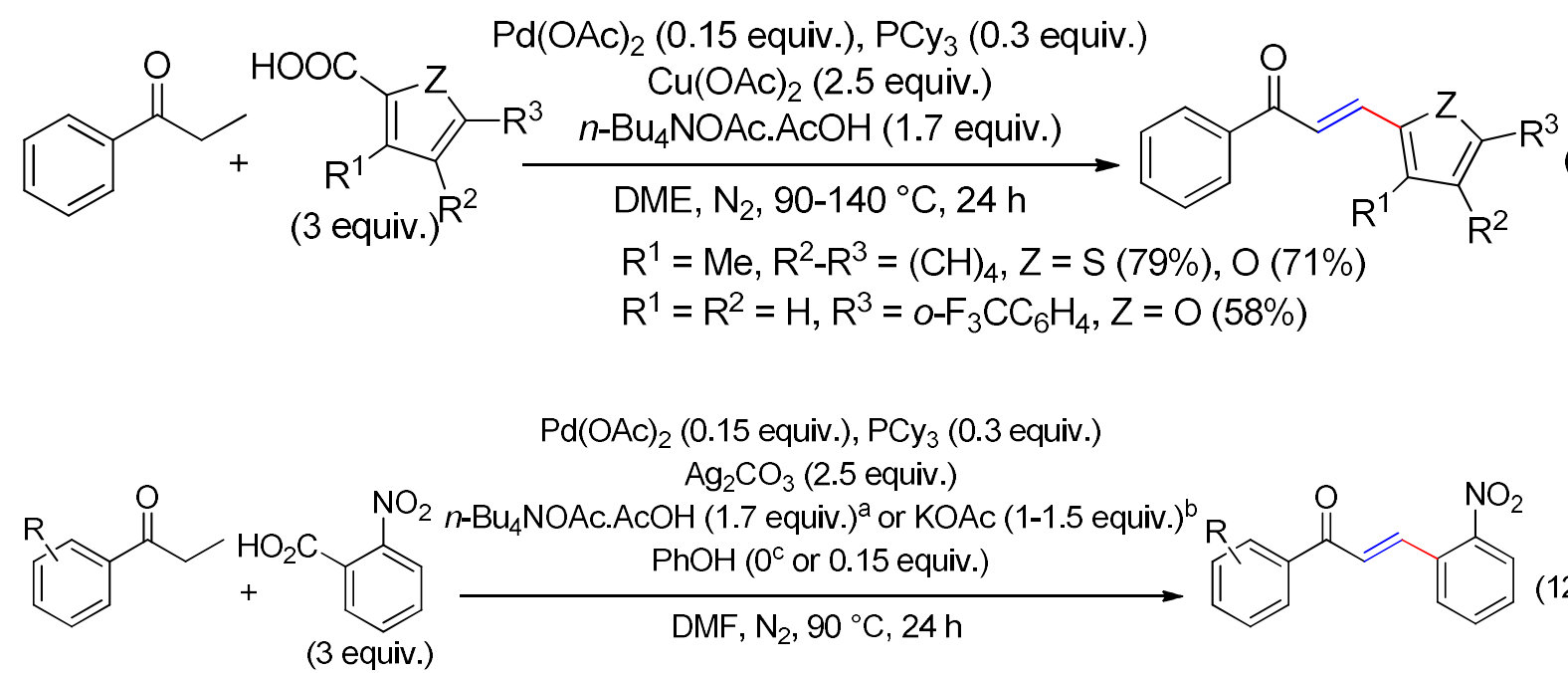

$\mathrm{R}=m-\mathrm{Me}^{\mathrm{a}}(70 \%), p-\mathrm{Me}^{\mathrm{a}}(64 \%), m-\mathrm{Ph}^{\mathrm{a}}(70 \%), p-\mathrm{Ph}^{\mathrm{a}}(72 \%), o-\mathrm{F}^{\mathrm{a}}(61 \%), m-\mathrm{F}^{\mathrm{b}}(61 \%), p-\mathrm{F}^{\mathrm{a}}(70 \%), m-\mathrm{Cl}^{\mathrm{b}, \mathrm{c}}(75 \%)$, $p-\mathrm{Cl}^{\mathrm{b}, \mathrm{c}}(82 \%), m-\mathrm{CF}_{3}{ }^{\mathrm{b}, \mathrm{c}}(73 \%), p-\mathrm{CF}_{3}^{\mathrm{b}, \mathrm{c}}(72 \%), m-\mathrm{CO}_{2} \mathrm{Me}^{\mathrm{b}, \mathrm{c}}(66 \%), m-\mathrm{CN}^{\mathrm{b}}(76 \%), m-\mathrm{NO}_{2}{ }^{\mathrm{b}}(62 \%)$

\section{Domino KTR + DHR}

The synthesis of 2-arylchromen-4-ones from KTR-DHR of chromanones has been described by Hong's team in 2012, using a large excess of arenes, $\mathrm{Pd}\left(\mathrm{OCOCF}_{3}\right)_{2}$ as the catalyst and a $\mathrm{Cu}\left(\mathrm{OCOCF}_{3}\right)_{2} / \mathrm{AgOAc}$ mixture as the oxidant in pivalic acid [Eq. (13)]. ${ }^{[45]}$ In contrast, the same procedure afforded the C3-product from 1-methyl-2,3-dihydroquinolin-4(1H)-one [Eq. (14)]. The KTR-DHR of various cyclic $\beta$-heteroatom-substituted ketones using acrylates 
instead of arenes was performed under slight different experimental conditions, leading also to $\mathrm{C} 3$-products [Eqs (15) and (16)].

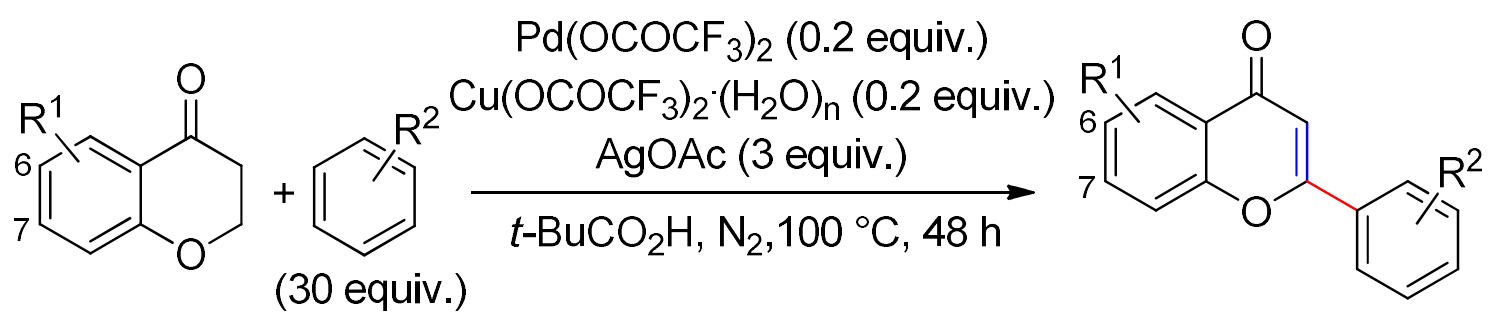

$$
\begin{aligned}
& \mathrm{R}^{1}=\mathrm{H}, \mathrm{R}^{2}=\mathrm{H}(89 \%), m-\mathrm{NO}_{2}(53 \%) \\
& \mathrm{R}^{2}=\mathrm{H}, \mathrm{R}^{1}=6-\mathrm{Me}(76 \%), 6-\mathrm{F}(83 \%), 7-\mathrm{OH}(68 \%), 7-\mathrm{OMe}(69 \%) \text {, } \\
& \text { 7-OAc (71\%), 7-OTf (79\%) }
\end{aligned}
$$<smiles>CN1C[C@H](c2ccccc2)CC(=O)c2ccccc21</smiles>

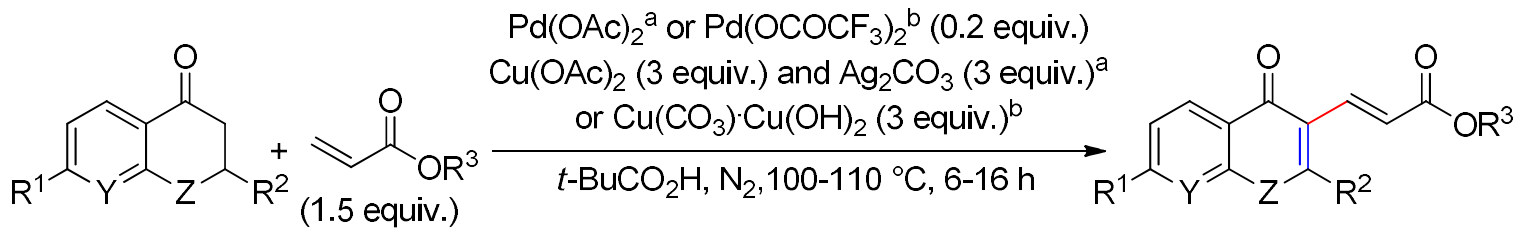

$$
\begin{aligned}
& \mathrm{R}^{1}=\mathrm{H}, \mathrm{Z}=\mathrm{O}, \mathrm{Y}=\mathrm{CH}, \mathrm{R}^{3}=t-\mathrm{Bu}, \mathrm{R}^{2}=\mathrm{H}\left(78 \%^{\mathrm{a}}\right) \\
& \mathrm{R}^{1}=\mathrm{H}, \mathrm{Z}=\mathrm{O}, \mathrm{Y}=\mathrm{CH}, \mathrm{R}^{3}=n-\mathrm{Bu}, \mathrm{R}^{2}=\operatorname{Ph}\left(50 \%^{\mathrm{a}}\right), \mathrm{Et}\left(61 \%{ }^{\mathrm{a}}\right), i-\operatorname{Pr}\left(54 \%^{\mathrm{a}}\right) \\
& \mathrm{R}^{1}=\mathrm{H}, \mathrm{Z}=\mathrm{NBn}, \mathrm{Y}=\mathrm{CH}, \mathrm{R}^{3}=t-\mathrm{Bu}, \mathrm{R}^{2}=\mathrm{H}\left(79 \%^{\mathrm{b}}\right) \\
& \mathrm{R}^{1}=\mathrm{Me}, \mathrm{Z}=\mathrm{NEt}, \mathrm{Y}=\mathrm{N}, \mathrm{R}^{3}=t-\mathrm{Bu}, \mathrm{R}^{2}=\mathrm{H}\left(93 \%^{\mathrm{b}}\right)
\end{aligned}
$$

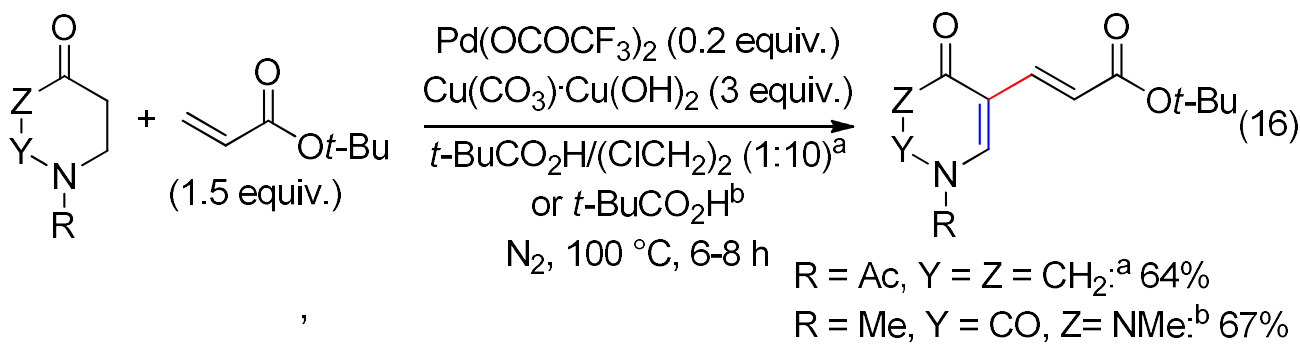

The regioselectivity of the KTR-DHR of

- chromanones with arenes [Eq. (13] ${ }^{[46]}$ is consistent with the DHR of chromones with arenes, ${ }^{[47]}$

- of chromanones and dihydroquinolin-4-ones [Eq. (15)] with acrylates is consistent with the DHR of chromones ${ }^{[48]}$ dihydropyranones, ${ }^{[49]}$ quinolones ${ }^{[50]}$ and cyclic enaminones ${ }^{[51]}$ with acrylates,

- 1,3-dimethyldihydropyrimidine-2,4(1H,3H)-dione [Eq. (16)] is consistent with the DHR of uracils with acrylates. ${ }^{[52]}$ 
The C3-arylation of 1-methyl-2,3-dihydroquinolin-4(1H)-one [Eq. (14)] was unexpected. ${ }^{[45]}$ In fact, the DHR of 1-methylquinolin-4-one with fluoroarenes also led to such regioselectivity ${ }^{[53]}$ Besides, modification of the common experimental conditions for the $\mathrm{Pd}^{\mathrm{II}}$ catalyzed cross-coupling of coumarins with arenes led to $\alpha$-arylation instead of the usual $\beta$ arylation. ${ }^{[54]}$ The DHRs involve two $\mathrm{C}\left(\mathrm{sp}^{2}\right)-\mathrm{H}^{\left[{ }^{[25]}\right.}$ We suspect that the regioselectivity of the above domino reactions could depend on the $\mathrm{C}-\mathrm{H}$ reacting with palladium. In the presence of acrylates, the heterocyclic substrate reacts first yielding the results depicted in Eqs (15) and (16). The arylation pathway was more subtle: C2-products as the main compounds ${ }^{[46]}$ when arenes react first [Eq. (13)] whereas C3-H of 1-methylquinolin-4(1H)-one is palladated ${ }^{[55]}$ before to react with benzene to afford the C3-product [Eq. (14)].

It is usually considered that the elimination of $\mathrm{HPdX}$ species requires the syn relationship between the palladium unit and the hydrogen. ${ }^{[16,56]}$ The insertion of the $\mathrm{C}=\mathrm{C}$ bond into $\mathrm{Ar}-\mathrm{Pd}^{\mathrm{II}}$ species being a syn process, ${ }^{[16,56,57]}$ there is no syn relationship between the palladium unit and the hydrogen geminal to the Ar group in the intermediates formed from above chromones (Scheme 4 ). Thus, the arylation compound is plausibly produced via an oxo- $\pi$-allylpalladium allowing epimerization of the carbon center, ${ }^{[58]}$ or from base-assisted reductive $\beta-\mathrm{H}$ elimination $^{[59]}$ (Scheme 4). ${ }^{[60,61]}$

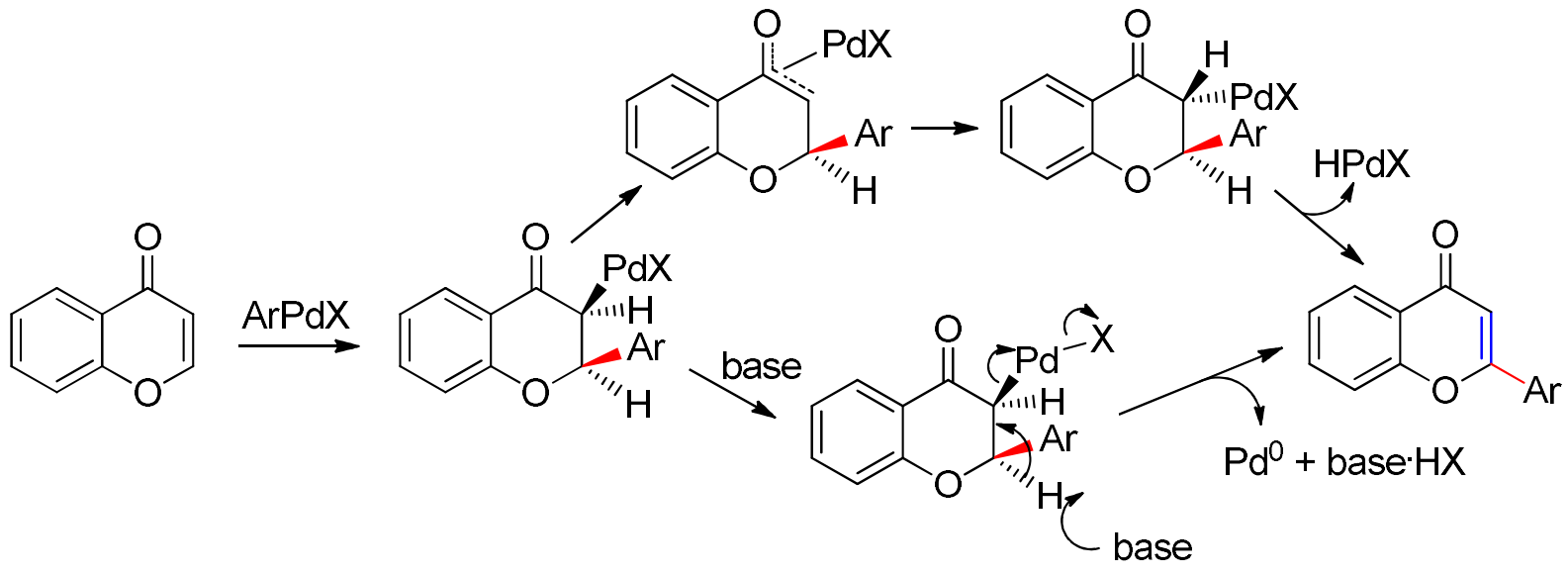

Scheme 4. The $\beta$-H elimination.

Su's team, who previously performed (KTR-DcHR)s [Eqs (10) to (12)], ${ }^{[43]}$ used again $\mathrm{Pd}(\mathrm{OAc})_{2} / \mathrm{PCy}_{3}$ and $\mathrm{Ag}_{2} \mathrm{CO}_{3}$ in DME, but with TEMPO as supplementary oxidant ${ }^{[62,63]}$ to carry out the KTR-DHR of propiophenones and 1-alkylpropanones with (hetero)arenes. ${ }^{\text {[64] }}$ With thiophenes, furans and indoles, optimum results were obtained with LiOAc or NaOAc as additional base [Eqs (17) to (19)]. The dehydrogenative cross-couplings between fluorobenzenes and propiophenones were effectively carried out with KF as the base and tetramethylene sulfoxide as ligand [Eq. (20)]. The KTR-DHR of 2,3,5,6-tetrafluoropyridine also occurred with a fair yield while that of benzene was disappointing [Eq. (20)]. It seems interesting to note the poor yield also achieved from the KTR-DHR of an unsubstituted heteroarene such as thiophene [Eq. (17)]. According to a set of experiments carried out to ascertain the formation mechanism of the arylation product, the cross-coupling arises effectively from the domino KTR-DHR, that is, successively, ketone dehydrogenation, palladoarylation, across insertion of the $\mathrm{C}=\mathrm{C}$ bond into the $\mathrm{Ar}-\mathrm{Pd}{ }^{\mathrm{II}}$ bond, and $\beta-\mathrm{H}$ elimination. 


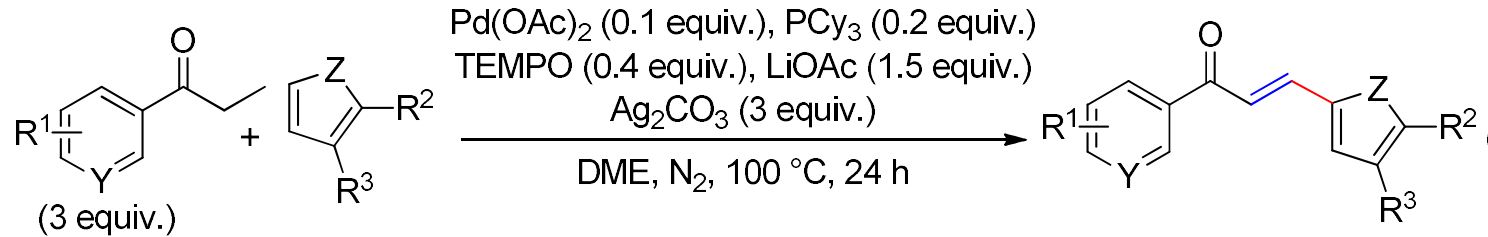

(3 equiv.)

$Y=C H, Z=S, R^{1}=R^{3}=H, R^{2}=H(24 \%), M e(85 \%), C O H(57 \%), C O M e\left(60 \%{ }^{a}\right), C O P h(70 \%)$, $\mathrm{Cl}\left(71 \%{ }^{\mathrm{a}}\right), \mathrm{Ph}(90 \%), \mathrm{CH}=\mathrm{CHCO}_{2} \mathrm{Me}\left(73 \%{ }^{\mathrm{b}}\right)$,

$\mathrm{Y}=\mathrm{CH}, \mathrm{Z}=\mathrm{S}, \mathrm{R}^{1}=\mathrm{H}, \mathrm{R}^{2}-\mathrm{R}^{3}=(\mathrm{CH})_{4}(55 \%)$

$\mathrm{Y}=\mathrm{CH}, \mathrm{Z}=\mathrm{O}, \mathrm{R}^{1}=\mathrm{R}^{3}=\mathrm{H}, \mathrm{R}^{2}=\mathrm{Me}(72 \%), \mathrm{CH}_{2} \mathrm{OAC}(56 \%)$

$\mathrm{Y}=\mathrm{CH}, \mathrm{Z}=\mathrm{S}, \mathrm{R}^{2}=\mathrm{Me}, \mathrm{R}^{3}=\mathrm{H}, \mathrm{R}^{1}=m-\mathrm{Me}\left(73 \%^{\mathrm{c}}\right), p-\mathrm{Me}(88 \%), \mathrm{o}-\mathrm{F}\left(72 \%^{\mathrm{c}}\right), m-\mathrm{F}\left(80 \%{ }^{\mathrm{c}}\right)$, $p-\mathrm{F}(80 \%), m-\mathrm{Cl}\left(82 \%{ }^{\mathrm{c}}\right), p-\mathrm{Cl}\left(80 \%{ }^{\mathrm{c}}\right), m-\mathrm{CF}_{3}\left(76 \%{ }^{\mathrm{c}}\right)$,

$p-\mathrm{CF}_{3}\left(74 \%{ }^{\mathrm{c}}\right), m-\mathrm{CN}\left(65 \%^{\mathrm{c}}\right), m-\mathrm{Ph}(83 \%), m-\mathrm{NO}_{2}\left(65 \%^{\mathrm{c}}\right)$,

$Y=N, Z=S, R^{2}=M e, R^{1}=R^{3}=H\left(53 \%{ }^{c}\right)$

$p$-OMe (75\%), $p-\mathrm{NMe}_{2}(44 \%), m-\mathrm{CO}_{2} \mathrm{Me}(70 \%)$

${ }^{a} \mathrm{NaOAC}$ instead of LiOAC

${ }^{\mathrm{b}} \mathrm{At} 120^{\circ} \mathrm{C}$

${ }^{\mathrm{CPCy}} \mathrm{H}_{3}(0.1$ equiv. $)$.

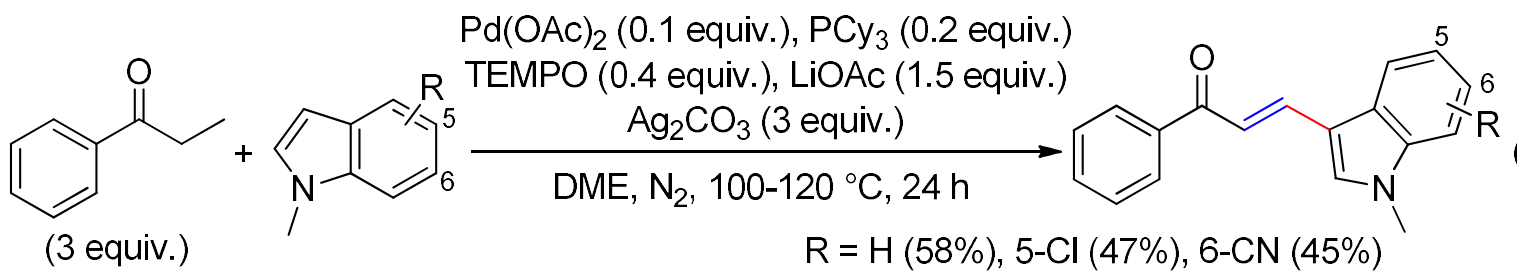

(3 equiv.)

$\mathrm{R}=\mathrm{H}(58 \%), 5-\mathrm{Cl}(47 \%), 6-\mathrm{CN}(45 \%)$

$\mathrm{Pd}(\mathrm{OAc})_{2}(0.1$ equiv. $), \mathrm{PCy}_{3}(0.1-0.2$ equiv. $)$
$\mathrm{TEMPO}(0.4$ equiv. $), \mathrm{LiOAc}^{(1.5}$ equiv. $)$
$\mathrm{Ag}_{2} \mathrm{CO}_{3}$ (3 equiv.)

$$
\begin{aligned}
& \mathrm{R}^{2}=\mathrm{Ph}, \mathrm{R}^{1}=i-\mathrm{Bu}(44 \%), i-\operatorname{Pr}(62 \%) \\
& \mathrm{R}^{2}=\mathrm{Me}, \mathrm{R}^{1}=\mathrm{Cy}(69 \%)
\end{aligned}
$$

(3 equiv.)

$\mathrm{R}^{1}=\mathrm{R}^{2}=\mathrm{H}, \mathrm{Z}=\mathrm{CH}\left(26 \%{ }^{\mathrm{a}}\right)$

$\mathrm{R}^{1}=\mathrm{H}, \mathrm{R}^{2}=\mathrm{F}, \mathrm{Z}=\mathrm{CF}(85 \%), \mathrm{COMe}(72 \%), \mathrm{CBr}(65 \%), \mathrm{CCN}\left(45 \%{ }^{\mathrm{b}}\right)$

$\mathrm{R}^{2}=\mathrm{F}, \mathrm{Z}=\mathrm{COMe}, \mathrm{R}^{1}=m-\mathrm{Br}(50 \%), p-\mathrm{Cl}(67 \%)$

$\mathrm{R}^{2}=\mathrm{F}, \mathrm{Z}=\mathrm{CF}, \mathrm{R}^{1}=m-\mathrm{F}(65 \%)$

$\mathrm{R}^{1}=\mathrm{H}, \mathrm{R}^{2}=\mathrm{F}, \mathrm{Z}=\mathrm{N}\left(61 \%{ }^{\mathrm{b}}\right)$

aUsing propiophenone/PhH/Pd(OAc) $)_{2} / \mathrm{LiOAc} / \mathrm{TEMPO} / \mathrm{Ag}_{2} \mathrm{CO}_{3} / \mathrm{DMSO}$ (1:125:0.1:1.5:3:16)

bWithout tetramethylene sulfoxide. 
Bäckvall and Gigant disclosed an aerobic KTR-DHR procedure ${ }^{[65]}$ using an electron-transfer mediator, the iron phthalocyanine $(\mathrm{Fe}(\mathrm{Pc}))$, which facilitates the catalyst re-oxidation to its active form by oxygen (Scheme 5). ${ }^{[66]}$ Heated in AcOH containing catalytic amounts of $\mathrm{Pd}(\mathrm{OAc})_{2}(\mathrm{DMSO})_{2}$, benzoquinone and $\mathrm{Fe}(\mathrm{Pc})$, a variety of substituted cyclohexanones and arenes led, under oxygen, to the corresponding $\beta$-arylated cyclohexenones except the 4acetamidocyclohexanone which afforded a 3:2 mixture of the $\alpha$ - and $\beta$-arylated isomers [Eq. (21)]. Coordinating properties of the acetamido unit could explain the inversion of the regioselectivity. Unsubstituted cyclohexanone and linear aliphatic ketones are decomposed under the reaction conditions, whereas the $\alpha, \beta$-diarylation product was obtained from indanone [Eq. (22)]. In contrast, benzosuberone was monoarylated [Eq. (23)].

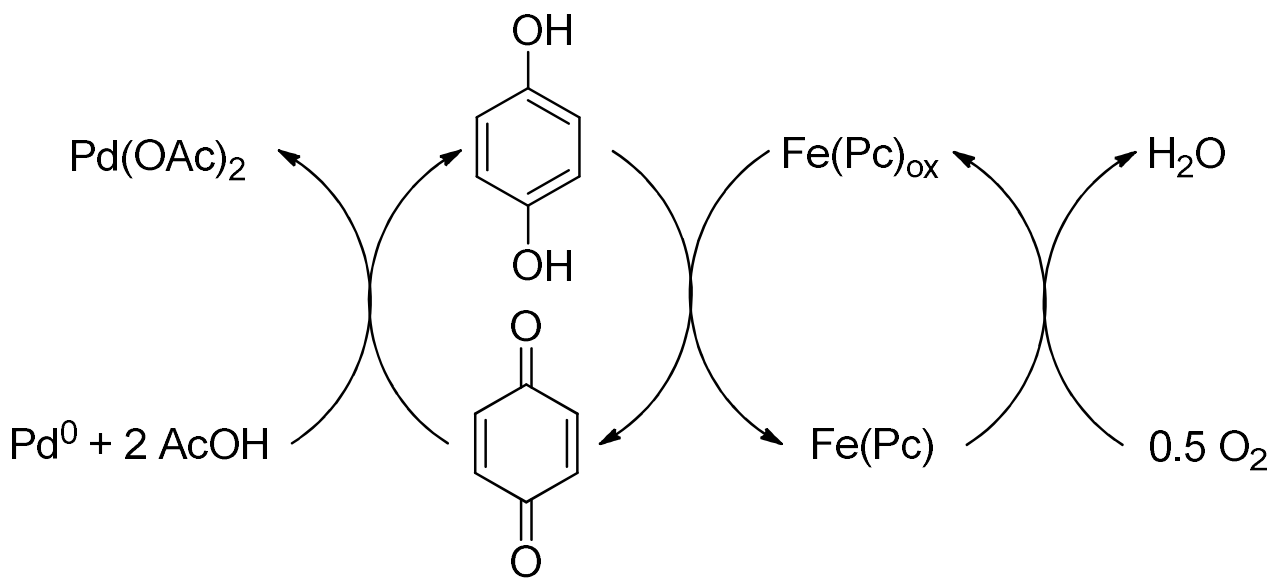

Scheme 5. Aerobic regeneration of $\mathrm{Pd}(\mathrm{OAc})_{2}$ through low-energy electron transfer involving a catalytic electron-transfer mediator.

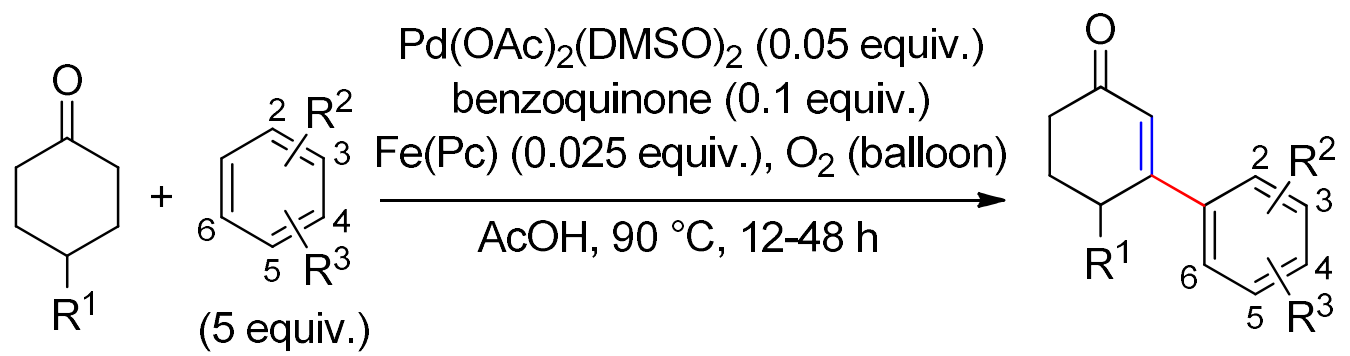

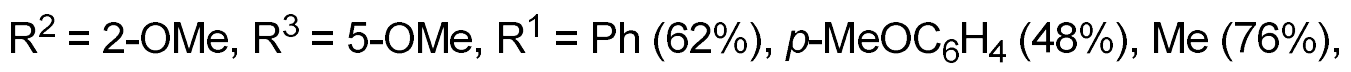

Et (58\%), $t$-Bu (53\%), $\mathrm{CF}_{3}(59 \%)$, OTBS (45\%), NHAc $\left(25 \%{ }^{\mathrm{a}}\right)$

$\mathrm{R}^{1}=\mathrm{Me}, \mathrm{R}^{2}=2-\mathrm{OMe}, \mathrm{R}^{3}=4-\mathrm{OMe}(54 \%), \mathrm{H}\left(83 \%{ }^{\mathrm{b}}\right)$

$\mathrm{R}^{1}=\mathrm{Me}, \mathrm{R}^{2}=3-\mathrm{Me}, \mathrm{R}^{3}=4-\mathrm{Me}(53 \%)$

$\mathrm{R}^{1}=\mathrm{Me}, \mathrm{R}^{2}=2-\mathrm{Me}, \mathrm{R}^{3}=5-\mathrm{Me}(64 \%)$

$R^{1}=M e, R^{2}=R^{3}=H\left(50 \%{ }^{c}\right)$

aplus $38 \%$ of the $\alpha$-arylation

bMixture of isomers, $o / \mathrm{m} / \mathrm{p}=24: 16: 60$

${ }^{\mathrm{C}}$ At $80{ }^{\circ} \mathrm{C}$ 


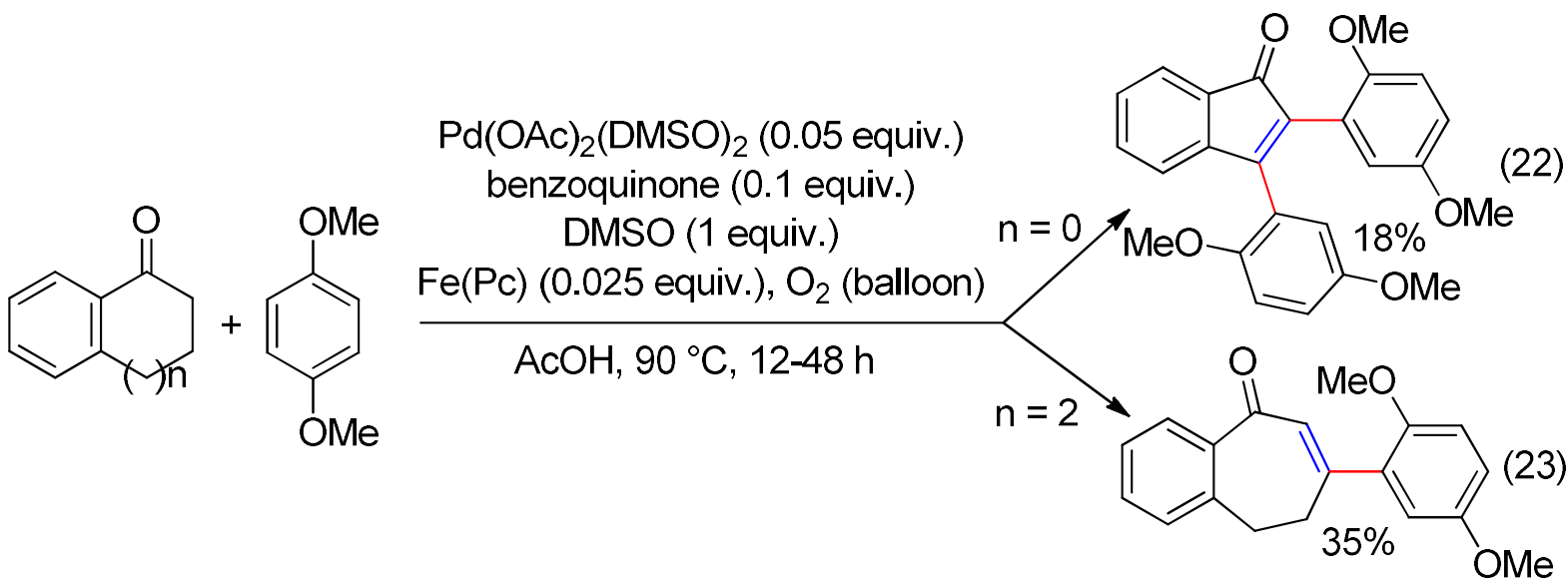

\section{Domino KTR + PHR}

The PHR reaction can arise using aryl halides as well as arenes since both arylating agents afford the same intermediate as previously depicted in Scheme 2. Thus, (KTR-PHR)s using either one or the other have been reported.

\subsection{Using aryl halides}

In 2002, Hartwig's team reported that the Pd-catalyzed reaction of lithium enolate of methyl isobutyrate with thirty nine bromo(hetero)arenes afforded selectively the $\alpha$-(hetero)arylation compound except with 2-bromothiophene which reacted to the $\alpha$ and $\beta$ positions [Eq. (24)]. The authors suspected the formation of the $\beta$-compound through a " $\alpha$-hydrogen elimination and reinsertion of the olefin into the metal hydride". ${ }^{67]}$

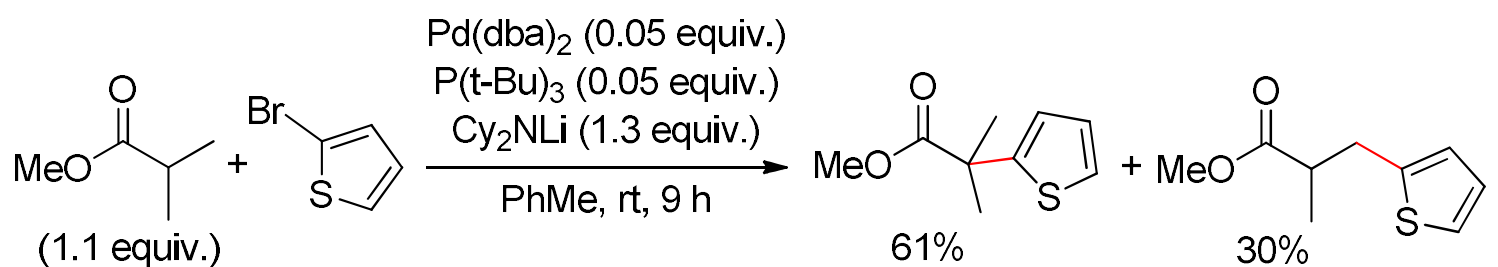

In 2010, Clot, Baudoin and co-workers disclosed experimental conditions leading, in most cases, to the selective $\beta$-(hetero)arylation of various ester enolates [Eq. (25)]. ${ }^{[68]}$

Subsequently, the same team related the strong dependence of both conversion and $\alpha / \beta$ selectivity on the nature of the ligand. ${ }^{[69]}$ For an example, the $\alpha / \beta$ ratio of the cross-coupling between $t$-butyl isobutyrate and 2-fluorobromobenzene was 85:15 with $\mathrm{P} t$ - $\mathrm{Bu}_{3}$, and $<2: 98$ with 2-dicyclohexylphosphanyl-2'-( $N, N$-dimethylamino)biphenyl [Eq. (25)]. Use of a chiral ligand led to cross-coupling products in fair yields and with enantioselectivities which remain to improve [Eq. (26)]. ${ }^{[68]}$ 


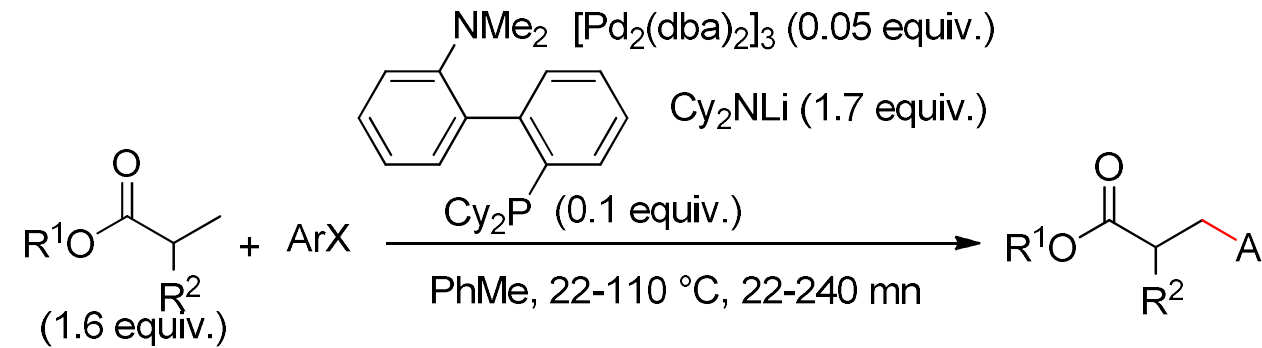

$$
\begin{gathered}
\mathrm{R}^{1}=\mathrm{R}^{2}=\mathrm{Me}, \mathrm{X}=\mathrm{Br}, \mathrm{Ar}=o-\mathrm{ClC}_{6} \mathrm{H}_{4}(82 \%), o-\mathrm{F}_{3} \mathrm{CC}_{6} \mathrm{H}_{4}(62 \%), o-\mathrm{MeC}_{6} \mathrm{H}_{4}\left(0 \%{ }^{\mathrm{a}}\right) \\
\mathrm{R}^{1}=t-\mathrm{Bu}, \mathrm{R}^{2}=\mathrm{Me}, \mathrm{X}=\mathrm{Br}, \mathrm{Ar}=\mathrm{Ph}\left(15 \%{ }^{\mathrm{b}}\right), o-\mathrm{FC}_{6} \mathrm{H}_{4}\left(63 \%{ }^{\mathrm{c}}\right), o-\mathrm{F}_{3} \mathrm{COC}_{6} \mathrm{H}_{4}(75 \%), \\
o-\mathrm{MeOC}_{6} \mathrm{H}_{4}(64 \%)
\end{gathered}
$$

$\mathrm{R}^{1}=\mathrm{R}^{2}=\mathrm{Me}, \mathrm{X}=\mathrm{Cl}, \mathrm{Ar}=$ thiophen-2-yl (69\%), 3-methylthiophen-2-yl (67\%)

$\mathrm{R}^{1}=t$-Bu, $\mathrm{R}^{2}=\mathrm{Me}, \mathrm{X}=\mathrm{Cl}, \mathrm{Ar}=$ pyridin-2-yl $\left(0 \%^{\mathrm{a}}\right)$, 3-fluoropyridin-2-yl $\left(56 \%^{\mathrm{d}}\right)$

$\mathrm{R}^{2}=\mathrm{Me}, \mathrm{X}=\mathrm{Br}, \mathrm{Ar}=0-\mathrm{ClC}_{6} \mathrm{H}_{4}, \mathrm{R}^{1}=n-\mathrm{Bu}(74 \%), t-\mathrm{Bu}(76 \%), i-\operatorname{Pr}(75 \%), \mathrm{Bn}(61 \%)$,

(Z)- $\left(\mathrm{CH}_{2}\right)_{2} \mathrm{CH}=\mathrm{CHEt}(68 \%)$

$\mathrm{R}^{1}=\mathrm{Me}, \mathrm{X}=\mathrm{Br}, \mathrm{Ar}=\mathrm{o}-\mathrm{ClC}_{6} \mathrm{H}_{4}, \mathrm{R}^{2}=\mathrm{CH}_{2}\left(\mathrm{o}-\mathrm{FC}_{6} \mathrm{H}_{3}\right)(67 \%), \mathrm{CF}_{3}(0 \%), \mathrm{Ph}(0 \%)$

$\mathrm{R}^{1}=\mathrm{Me}, \mathrm{X}=\mathrm{Br}, \mathrm{Ar}=0-\mathrm{FC}_{6} \mathrm{H}_{4}, \mathrm{R}^{2}=\mathrm{NBn}_{2}(63 \%)$

${ }^{a} \alpha$-arylation only.

bPlus $\alpha$-arylation (68\%).

${ }^{c} \alpha / \beta$ ratio: $<2: 98$.

dPlus $\alpha$-arylation (14\%).

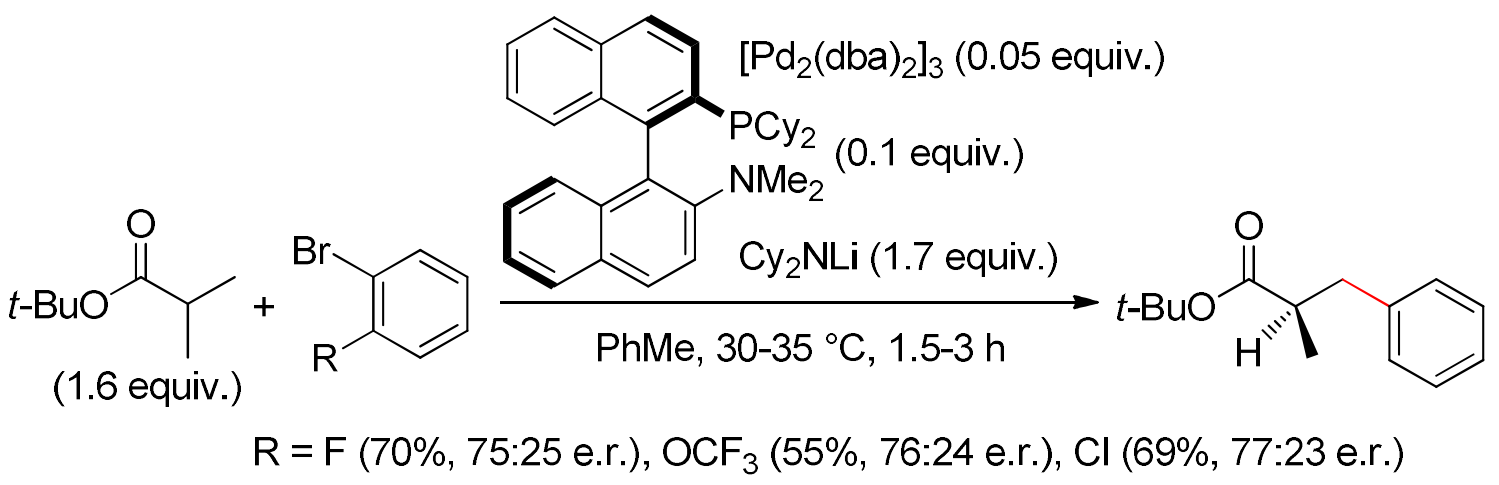

Analysis of the reactivity of deuterated esters led the Clot and Baudoin team to exclude a direct $\beta-\mathrm{C}\left(\mathrm{sp}^{3}\right)-\mathrm{H}$ activation and to propose a mechanism supported by computational studies. ${ }^{[69]}$ Trans-metalation of the lithium enolate with the arylpalladium complex affords palladium enolate 6A (Scheme 6). The agnostic Pd-H liaison may favor the formation of olefin complex $6 \mathrm{~B}$ rather than the reductive elimination leading to the $\alpha$-arylated product. Bond rotation gives isomeric complex $\mathbf{6 C}$. Subsequent insertion of the $\mathrm{C}=\mathrm{C}$ bond into the $\mathrm{H}$ $\mathrm{Pd}$ bond provides palladium homoenolate $6 \mathrm{D}$ which undergoes reductive elimination to provide the $\beta$-arylated product. According to this catalytic cycle and despite the absence of free $\alpha, \beta$-unsaturated ester, this $\beta$-arylation corresponds to a domino KTR-PHR. That led us to suspect that some other Pd-catalyzed $\beta-\mathrm{C}\left(\mathrm{sp}^{3}\right)-\mathrm{H}$ functionalizations of carbonyl compounds could also involve an intermediate dehydrogenation reaction. ${ }^{[70]}$ 


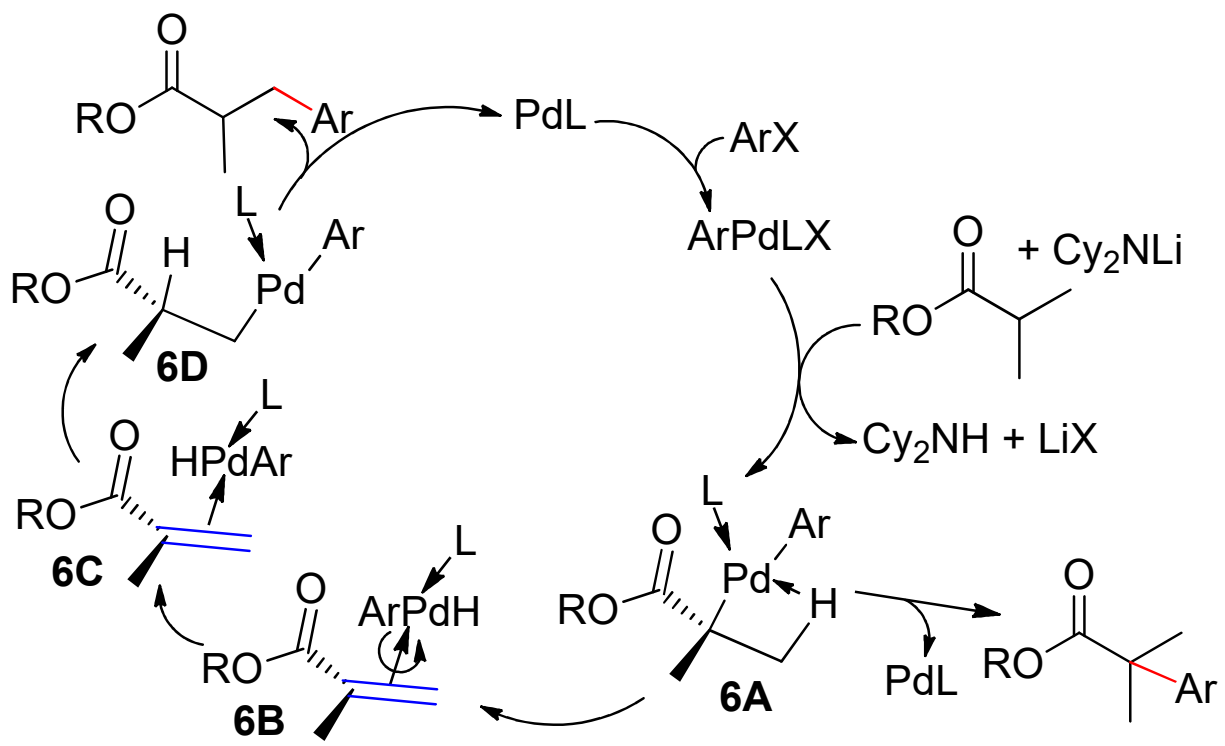

Scheme 6. Mechanism of the $\alpha$ - and $\beta$-arylation of alkyl isobutyrate.

Dong and Huang disclosed the $\beta$-arylation of cyclic and linear ketones as well as chromanone, with aryl iodides [Eq. (27) to (31)]. ${ }^{[28]}$ Catalyzed by the $\mathrm{Pd}\left(\mathrm{OCOCF}_{3}\right)_{2} / \mathrm{P}(i \text {-Pr })_{3}$ association, this KTR-PHR occurred at $80{ }^{\circ} \mathrm{C}$ in a hexafluoro-2-propanol/dioxane mixture containing $\mathrm{Ag}\left(\mathrm{OCOCF}_{3}\right)_{2}$ or $\mathrm{Cu}\left(\mathrm{OCOCF}_{3}\right)_{2}$ to regenerate $\mathrm{Pd}^{\mathrm{II}}$ species. No arylation was observed in the absence of the oxidant, while the main product was the self-coupling of the aryl iodide in the absence of the phosphine [Eq. (27)]. The formation of the diarylated compound from propiophenone [Eq. (31)] was attributed to a domino process involving four successive 
reactions: KTR, PHR, KTR and PHR. ${ }^{[28]}$ Preliminary studies using 1-bromo-3,5dimethoxybenzene indicated that aryl bromides would be suitable for the above (KTR-PHR)s.<smiles>[R]c1cccc(I)c1</smiles>

(2.5 equiv.)

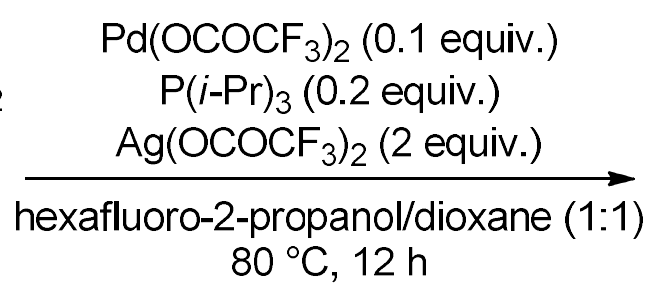

$80^{\circ} \mathrm{C}, 12 \mathrm{~h}$<smiles>[R]c1cccc(C2CC(=O)CCC2[R])c1</smiles>

$\mathrm{R}^{1}=\mathrm{H}, \mathrm{R}^{2}=\mathrm{H}(72 \%)^{\mathrm{a}, \mathrm{b}, \mathrm{c}}, \mathrm{o}-\mathrm{Me}(70 \%), p-\mathrm{Me}(65 \%), p-\mathrm{CO}_{2} \mathrm{Me}(96 \%), m-\mathrm{OMe}(80 \%)$

p-OMe (52\%), p-Ph (65\%), p-morpholinosulfonyl) (88\%),

$p-\mathrm{F}(65 \%), m-\mathrm{Cl}(64 \%), p-\mathrm{CN}(70 \%), p-\mathrm{NO}_{2}(57 \%), p-\mathrm{Ac}(70 \%)$, $p$-NAc $(77 \%), p-\mathrm{COH}(63 \%), p-\mathrm{CONMe}(\mathrm{OMe})(88 \%)$

$\mathrm{R}^{2}=p-\mathrm{CO}_{2} \mathrm{Me}, \mathrm{R}^{1}=\mathrm{Me}(56 \%,>20: 1$ d.r. $), \mathrm{Ph}(45 \%,>20: 1$ d.r. $)$

${ }^{a}$ In the absence of $\mathrm{P}(i-\mathrm{Pr})_{3}: 4 \%$ and formation of $\mathrm{Ph}-\mathrm{Ph}(56 \%)$

$\mathrm{b}_{63}-72 \%$ with $\mathrm{Cu}\left(\mathrm{OCOCF}_{3}\right)_{2} \cdot \mathrm{XH}_{2} \mathrm{O}$ instead of $\mathrm{Ag}\left(\mathrm{OCOCF}_{3}\right)_{2}$

In the absence of $\mathrm{Ag}\left(\mathrm{OCOCF}_{3}\right)_{2}: 0 \%$

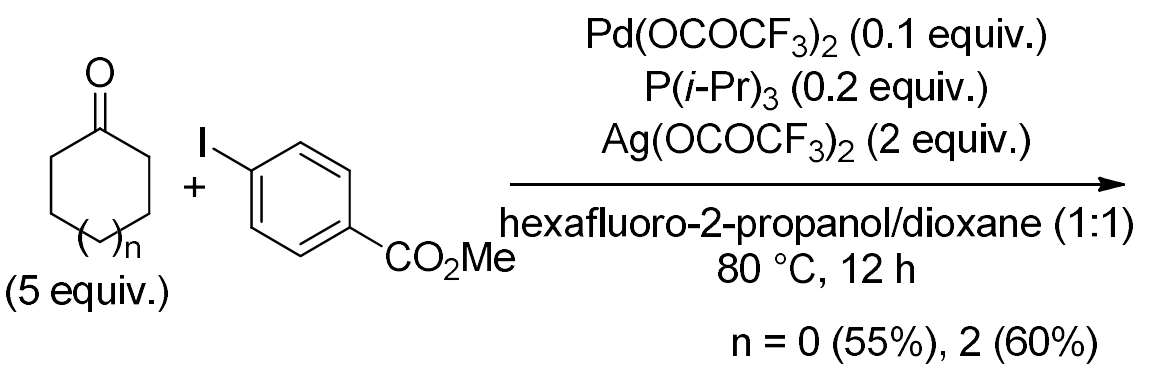<smiles>CC(=O)c1ccc(C2CCCCC2)cc1</smiles>

$$
n=0(55 \%), 2(60 \%)
$$<smiles>O=C1C[CH+]c2ccccc2O1</smiles>
(2.5 equiv.)
$\mathrm{Pd}\left(\mathrm{OCOCF}_{3}\right)_{2}(0.1$ equiv. $)$

$\mathrm{P}(i-\mathrm{Pr})_{3}(0.2$ equiv. $)$

$\mathrm{Ag}\left(\mathrm{OCOCF}_{3}\right)_{2}$ (2 equiv.)

hexafluoro-2-propanol/dioxane (1:1) $80^{\circ} \mathrm{C}, 12 \mathrm{~h}$<smiles>O=C1CC(c2ccccc2)Oc2ccccc21</smiles><smiles>[R]CCC([R])=O</smiles>

$\mathrm{Pd}\left(\mathrm{OCOCF}_{3}\right)_{2}(0.1$ equiv. $)$ $\mathrm{P}(i-\mathrm{Pr})_{3}(0.2$ equiv. $)$

(5-10 equiv.) $\mathrm{Ag}\left(\mathrm{OCOCF}_{3}\right)_{2}$ (2 equiv.)

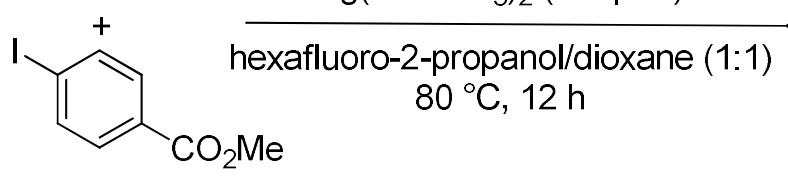

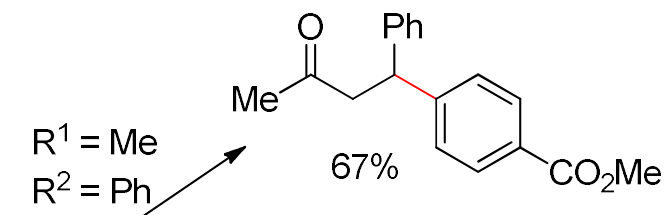
$\mathrm{R}^{2}=\mathrm{H}$

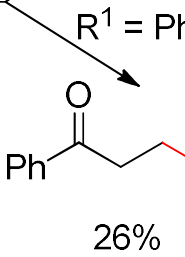<smiles>[R]=[V]</smiles><smiles>COC(C)C(C)OC</smiles> 


\subsection{Using arenes}

In treating a 3:2 mixture of ethyl 2-oxocyclopentanecarboxylate and 1,3,5-trimethoxybenzene with $\mathrm{Pd}(\mathrm{OAc})_{2}$ catalyst in $\mathrm{AcOH} /$ dichloroethane at $50{ }^{\circ} \mathrm{C}$ under oxygen, Pihko and coworkers isolated a 1.5:1 mixture of the KTR-PHR and KTR-DHR products. ${ }^{[71]}$ A survey of different Brönsted acids as additives revealed the strong promotion of the PHR by diphenyl phosphate which, consequently, was used for a number of cross-couplings between $\beta$ dicarbonyl compounds and trialkoxybenzenes [Eq. (32)]. The domino reaction was inefficient with arenes bearing two donor groups such as 1,3-dimethoxybenzene but, under modified conditions, occurred with unprotected phenols [Eq. (33)].

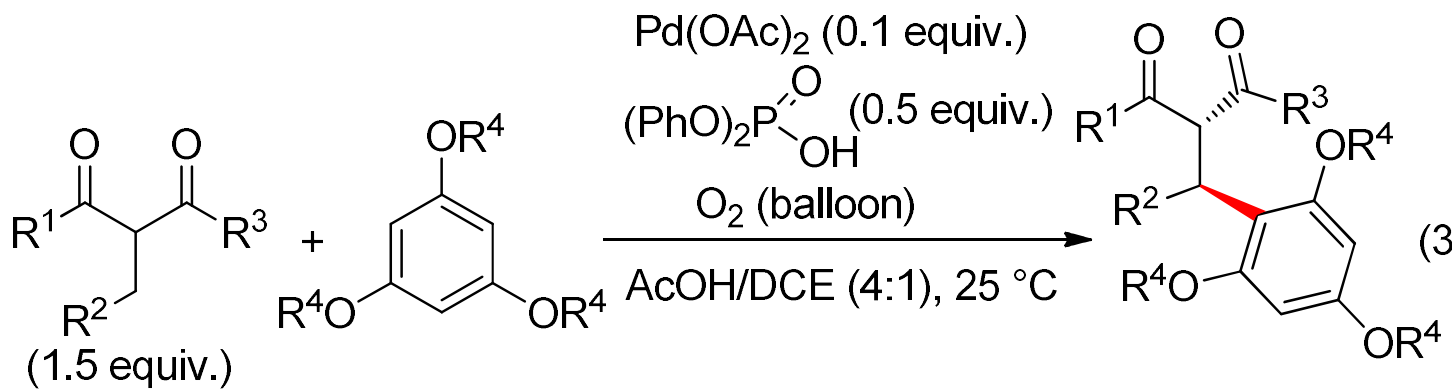

(1.5 equiv.)

$\mathrm{R}^{1}-\mathrm{R}^{2}=\left(\mathrm{CH}_{2}\right)_{2}, \mathrm{R}^{4}=\mathrm{Me}, \mathrm{R}^{3}=\mathrm{OMe}(80 \%)$, OEt (87\%), OBn (76\%), Oi-Pr $(81 \%)$

$\mathrm{R}^{1}-\mathrm{R}^{2}=\left(\mathrm{CH}_{2}\right)_{2}, \mathrm{R}^{3}=\mathrm{OEt}, \mathrm{R}^{4}=\mathrm{Et}(72 \%)$

$\mathrm{R}^{1}-\mathrm{R}^{2}=\left(\mathrm{CH}_{2}\right)_{4}, \mathrm{R}^{3}=\mathrm{OMe}, \mathrm{R}^{4}=\mathrm{Me}(53 \%)$

$\mathrm{R}^{1}-\mathrm{R}^{2}=\mathrm{OCH}_{2}, \mathrm{R}^{3}=\mathrm{Me}, \mathrm{R}^{4}=\mathrm{Me}(62 \%)$

$\mathrm{R}^{1}=\mathrm{Me}, \mathrm{R}^{2}=\mathrm{H}, \mathrm{R}^{3}=\mathrm{OEt}, \mathrm{R}^{4}=\mathrm{Et}\left(62 \%{ }^{\mathrm{a}}\right)$

apd $\left(\mathrm{OCOCF}_{3}\right)_{2}$ as catalyst.

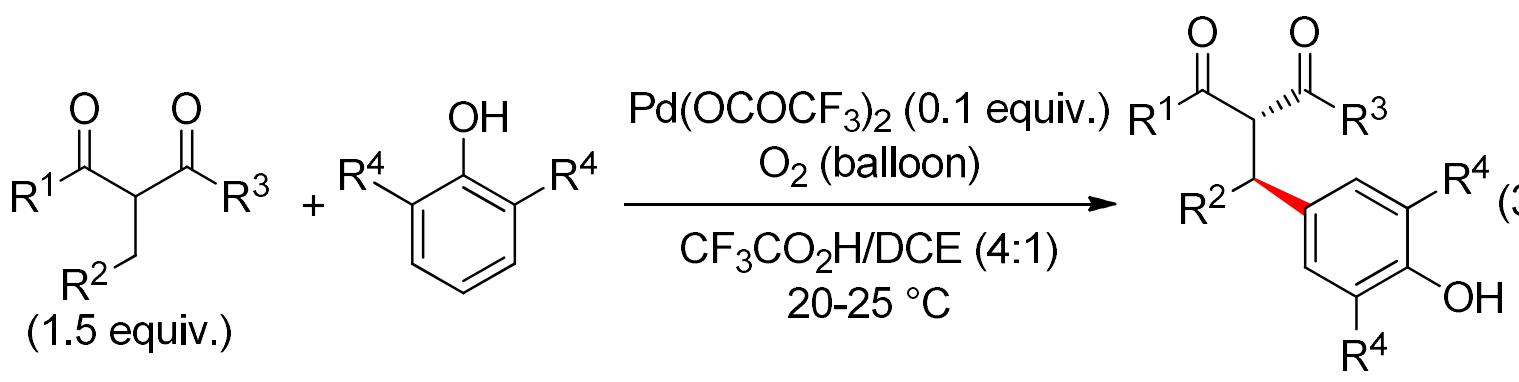

$\mathrm{R}^{1}-\mathrm{R}^{2}=\left(\mathrm{CH}_{2}\right)_{2}, \mathrm{R}^{4}=\mathrm{H}, \mathrm{R}^{3}=\mathrm{OEt}(72 \%), \mathrm{OBn}(58 \%)$

$\mathrm{R}^{1}-\mathrm{R}^{2}=\left(\mathrm{CH}_{2}\right)_{2}, \mathrm{R}^{3}=\mathrm{OEt}, \mathrm{R}^{4}=\mathrm{Me}(85 \%), i-\operatorname{Pr}(61 \%), \mathrm{Ot}-\mathrm{Bu}(63 \%)$, OMe $(70 \%)$

$\mathrm{R}^{1}-\mathrm{R}^{2}=\mathrm{OCH}_{2}, \mathrm{R}^{4}=\mathrm{Me}, \mathrm{R}^{3}=\mathrm{Me}(68 \%), i-\operatorname{Pr}(59 \%)$

$\mathrm{R}^{1}-\mathrm{R}^{2}=\mathrm{OCH}_{2}, \mathrm{R}^{4}=\mathrm{H}, \mathrm{R}^{3}=i-\operatorname{Pr}(53 \%)$

$\mathrm{R}^{1}=\mathrm{Me}, \mathrm{R}^{2}=\mathrm{H}, \mathrm{R}^{3}=\mathrm{OEt}, \mathrm{R}^{4}=\mathrm{H}(56 \%)$, Me (61\%)

From a set of experiments, the authors proposed that the $\beta$-arylation of 1,3-dicarbonyl compounds with trialkoxybenzenes occurs via an "early-arylation" pathway $(b)$ rather than the usually admitted "late-arylation" pathway (a) (Scheme 7). ${ }^{[71]}$ Diphenyl phosphate would promote the formation of cationic arylpalladium complex $\mathbf{7 A}$, which would mediate the 
dehydrogenation leading to $\mathbf{7 B}$. The latter would evolve via either arene or hydride insertion to afford $\mathbf{7 C}$ or $\mathbf{7 D}$, respectively. Subsequent reductive elimination of $\mathrm{Pd}^{0}$ would afford the product $(\mathbf{7 E})$. Note that the delivery of $7 \mathbf{E}$ is accompanied by the formation of either $\mathrm{Pd}^{0}$ or $\mathrm{Pd}^{\mathrm{II}}$, depending on the reaction pathway. The authors mention a plausible "interceptedarylation" pathway $(c)$ mediated by diphenyl phosphate, leading to 7B from 7F.

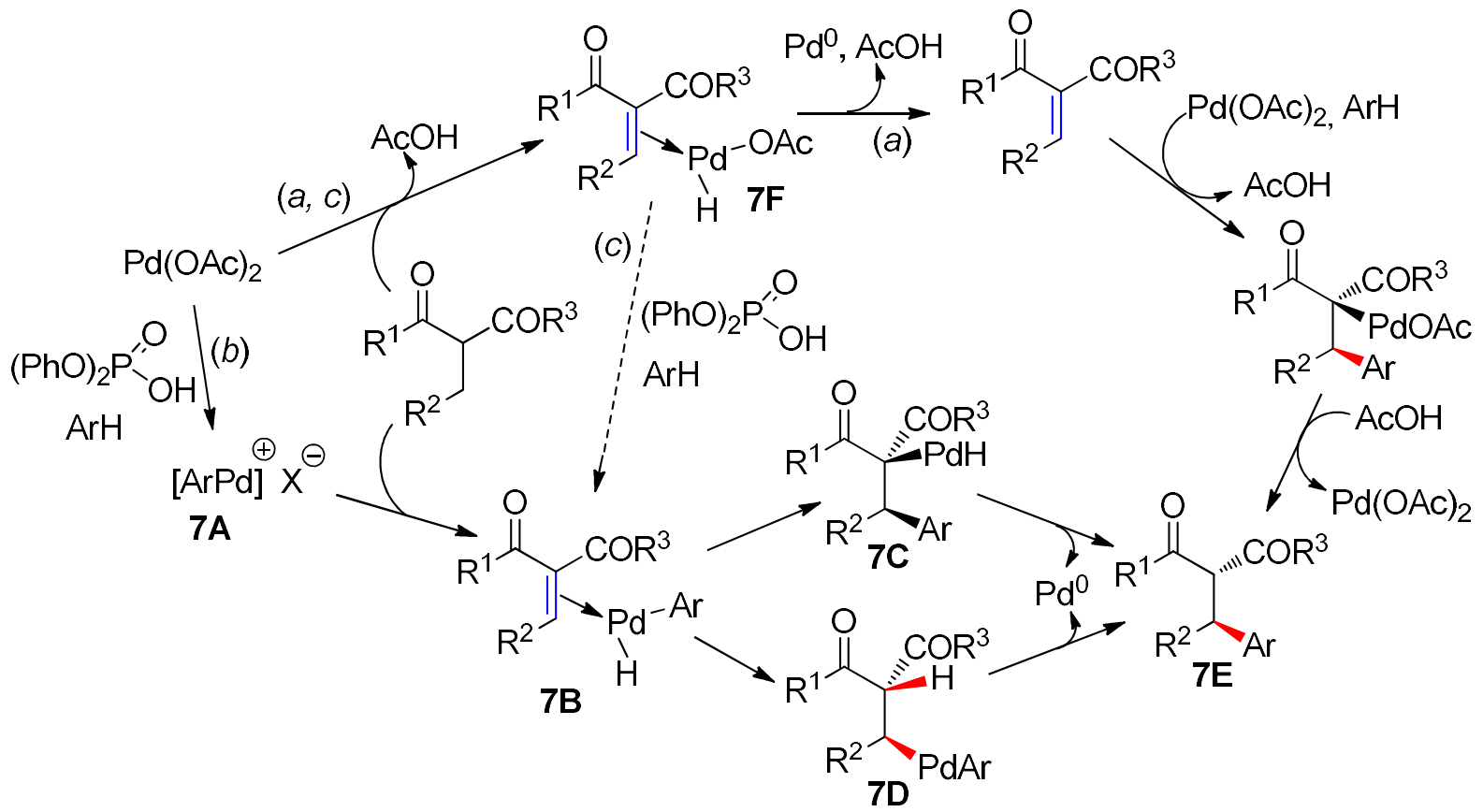

Scheme 7. $\beta$-Arylation of 1,3-dicarbonyl compounds: "late-arylation" pathway $(a)$ versus "early-arylation" pathway $(b)$ or "intercepted-arylation" pathway $(c)$.

Pihko's team also studied the KTR-PHR of $\beta$-dicarbonyl compounds with indoles. ${ }^{[29,72]}$ The optimum conditions differ from those disclosed in Eqs (32) and (33), $t$-butyl perbenzoate being the best oxidant [Eq. (34)]. Diastereoselective cross-couplings were effectively performed using 8-phenylmenthyl 2-oxocyclopentanecarboxylate, even with a bromine substituent in the indole nucleus [Eq. (35)]. ${ }^{[29]}$ 
<smiles>[R]CC(C([R])=O)C([R])=O</smiles>
(1.5 equiv.)

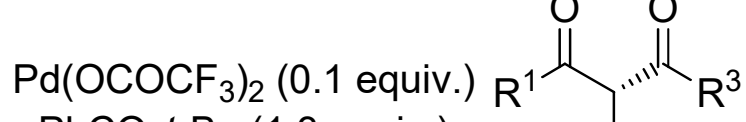
$\mathrm{PhCO}_{3} t-\mathrm{Bu}(1.3$ equiv.)

$i-\mathrm{PrOH} / \mathrm{AcOH}(4: 1), 25^{\circ} \mathrm{C}$

$\mathrm{R}^{2}$<smiles>[Z20]C(C)c1cn([AlH2])c2ccccc12</smiles>

$R^{1}-R^{2}=\left(C_{2}\right)_{2}, R^{4}=M e, R^{5}=H, R^{3}=$ OMe $(78 \%)$, OEt $\left(79 \%{ }^{a}\right), O_{2} H_{2} C F_{3}(55 \%)$, OBn (74\%), Ot-Bu (80\%)

$\mathrm{R}^{1}-\mathrm{R}^{2}=\left(\mathrm{CH}_{2}\right)_{3}, \mathrm{R}^{3}=\mathrm{OEt}, \mathrm{R}^{4}=\mathrm{Me}, \mathrm{R}^{5}=2-\mathrm{Me}(70 \%)$

$\mathrm{R}^{1}-\mathrm{R}^{2}=\left(\mathrm{CH}_{2}\right)_{4}, \mathrm{R}^{3}=\mathrm{OMe}, \mathrm{R}^{4}=\mathrm{Me}, \mathrm{R}^{5}=2-\mathrm{Me}(61 \%)$

$R^{1}-R^{2}=\mathrm{OCH}_{2}, R^{3}=\mathrm{Me}, \mathrm{R}^{4}=\mathrm{Me}, \mathrm{R}^{5}=\mathrm{H}(63 \%)$

$\mathrm{R}^{1}-\mathrm{R}^{2}=\mathrm{OCH}_{2}, \mathrm{R}^{4}=\mathrm{Me}, \mathrm{R}^{5}=2-\mathrm{Me}, \mathrm{R}^{3}=i-\operatorname{Pr}(53 \%), \mathrm{CH}_{2}$ allyl (53\%)

$R^{1}=M e, R^{2}=H, R^{3}=$ OEt, $R^{4}=M e, R^{5}=H\left(54 \%{ }^{b}\right)$, Me (55\%)

$\mathrm{R}^{1}-\mathrm{R}^{2}=\left(\mathrm{CH}_{2}\right)_{2}, \mathrm{R}^{3}=\mathrm{OEt}, \mathrm{R}^{4}=\mathrm{Me}, \mathrm{R}^{5}=2-\mathrm{Me}(84 \%), 5-\mathrm{Br}(86 \%), 6-\mathrm{CO}_{2} \mathrm{Me}(67 \%)$, $6-\mathrm{Cl}(81 \%)$

$\mathrm{R}^{1}-\mathrm{R}^{2}=\left(\mathrm{CH}_{2}\right)_{2}, \mathrm{R}^{3}=\mathrm{OEt}, \mathrm{R}^{4}=\mathrm{H}, \mathrm{R}^{5}=\mathrm{H}(94 \%), 5-\mathrm{Me}(74 \%), 5-\mathrm{OMe}(87 \%), 2-\mathrm{Ph}(96 \%)$ $\mathrm{R}^{1}-\mathrm{R}^{2}=\left(\mathrm{CH}_{2}\right)_{2}, \mathrm{R}^{3}=\mathrm{OEt}, \mathrm{R}^{4}=\mathrm{Bn}, \mathrm{R}^{5}=\mathrm{H}(83 \%)$

aOther oxidants: $\mathrm{O}_{2}$ (1atm., 64\%), $\mathrm{H}_{2} \mathrm{O}_{2}$ (46\%), $t$-BuOOH (67\%), $t$-BuOOt-Bu (26\%), $t$-BuOOAc (72\%), $\mathrm{PhCMe}{ }_{2} \mathrm{OOH}(57 \%), \mathrm{BzOOBz}(37 \%), \mathrm{AgOAc}(42 \%)$, Oxone (35\%), $\mathrm{K}_{2} \mathrm{~S}_{2} \mathrm{O}_{8}(59 \%), \mathrm{MnO}_{2}(58 \%)$.

bUsing 4.5 equiv. of ethyl 2-methyl-3-oxobutanoate.<smiles>[R]n1ccc2ccccc21</smiles>

(1.5 equiv.)
$\mathrm{Pd}\left(\mathrm{OCOCF}_{3}\right)_{2}(0.1$ equiv.) $\mathrm{PhCO}_{3} t-\mathrm{Bu}(1.3$ equiv.) i-PrOH/AcOH (4:1), $25^{\circ} \mathrm{C}$

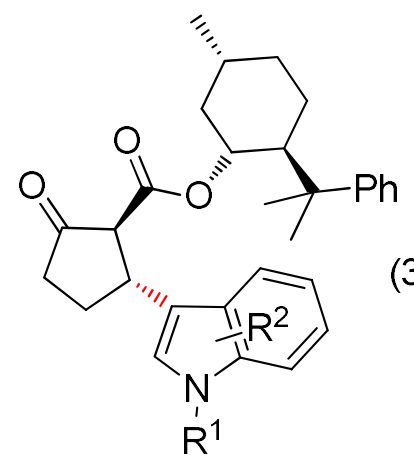

$\mathrm{R}^{1}=\mathrm{Me}, \mathrm{R}^{2}=\mathrm{H}(69 \%, 20: 1$ d.r. $), 2-\mathrm{Ph}(54 \%,>25: 1$ d.r. $), 5-\mathrm{Br}(59 \%, 10.4: 1$ d.r. $)$

$R^{1}=H, R^{2}=H(68 \%, 8.6: 1$ d.r. $), 4-B r(53 \%, 2.1: 1$ d.r. $), 5-B r(59 \%, 14: 1$ d.r. $)$, 5 -OMe $(41 \%, 13: 1$ d.r. $)$

$R^{1}=B n, R^{2}=H(55 \%, 25.5: 1$ d.r. $)$

Kinetic experiments, isotope effects, deuterated starting materials, ${ }^{1} \mathrm{H}$ NMR monitoring and DFT calculations led the authors to assume the mechanism depicted in Scheme 8 for the cross-coupling between ethyl 2-oxocyclopentanonecarboxylate and $N$-methylindole $(\mathbf{8 A}){ }^{\left[{ }^{29,72]}\right.}$ The proposal highlights the unexpected role of the indole, particularly in the assistance of the dehydrogenation reaction. Indeed, $\mathbf{8 A}$ is involved in the early stage of the reaction as ligand leading to complex $\mathbf{8 B}$, which mediates the KTR. Trifluoroacetic acid and $t$-butyl perbenzoate jointly assumed the regeneration of $\mathbf{8 B}$, which also mediates the PHR. 


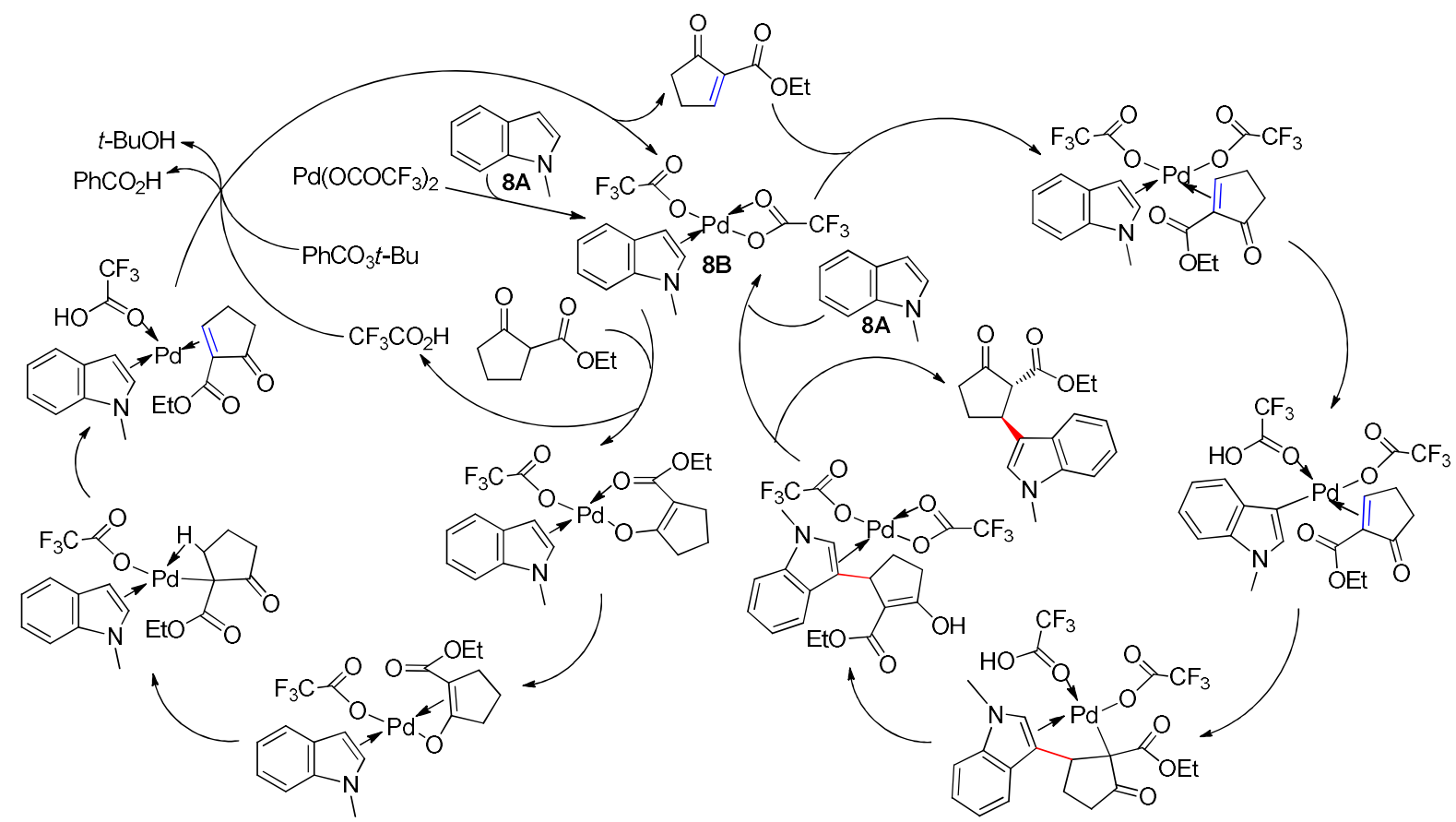

Scheme 8. A KTR-PHR using $N$-methylindole as both ligand and reagent.

\section{Domino OHR + KTR + PHR}

Piko's team performed three-component domino reactions between $\beta$-ketoesters, indoles and aryl boronates under experimental conditions [Eq. (36)] close to those used in the absence of the third component [see Eqs (34) and (35)]. ${ }^{[73]}$ Studies of two-component coupling experiments led to favor a domino reaction involving firstly the coupling between the indole and the arylboronate ${ }^{[74]}$ and subsequent reaction of the resulting OHR product with the dehydrogenated $\beta$-ketoester, as depicted in Scheme 9. Control experiments have nevertheless shown that the KTR-PHR product independently obtained from $\beta$-ketoester/indole coupling (see Subchapter 6.2) reacts with the aryboronate to also afford the three-component product, but that would be, at the best, a minor reaction pathway under the three-component domino reactions conditions.

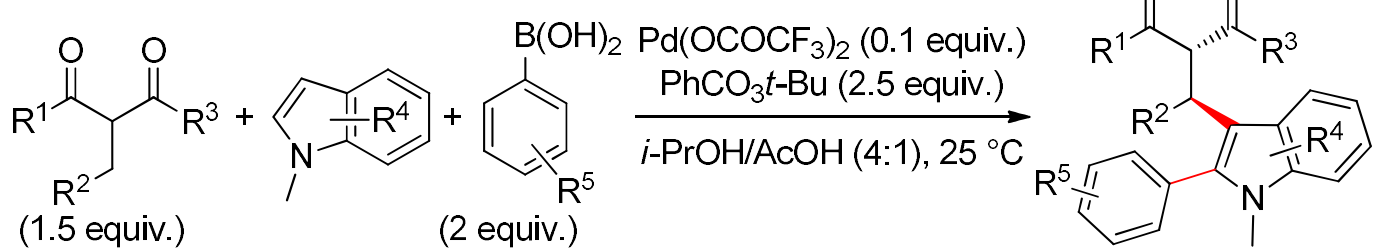

$\mathrm{R}^{1}-\mathrm{R}^{2}=\left(\mathrm{CH}_{2}\right)_{2}, \mathrm{R}^{3}=\mathrm{OEt}, \mathrm{R}^{4}=\mathrm{H}, \mathrm{R}^{5}=\mathrm{H}(76 \%), \mathrm{o}-\mathrm{Me}(62 \%), \mathrm{o}-(\mathrm{i}-\mathrm{Pr})(69 \%), p-\mathrm{Me}(75 \%), p-(t-\mathrm{Bu})(77 \%)$, $p-\mathrm{Cl}(63 \%), p-\mathrm{F}(64 \%), p-\mathrm{OH}(62 \%), p-\mathrm{CO}_{2} \mathrm{Et}(54 \%)$

$\mathrm{R}^{1}-\mathrm{R}^{2}=\left(\mathrm{CH}_{2}\right)_{2}, \mathrm{R}^{3}=\mathrm{OEt}, \mathrm{R}^{5}=\mathrm{H}, \mathrm{R}^{4}=5-\mathrm{Me}(67 \%), 5-\mathrm{OMe}(73 \%), 5-\mathrm{CO}_{2} \mathrm{Me}(61 \%)$

$\mathrm{R}^{1}-\mathrm{R}^{2}=\left(\mathrm{CH}_{2}\right)_{2}, \mathrm{R}^{3}=$ Omenthyl, $\mathrm{R}^{4}=\mathrm{H}, \mathrm{R}^{4}=0-\mathrm{Me}(65 \%, 1.8: 1 \mathrm{dr}), p-(t-\mathrm{Bu})(61 \%, 3: 1 \mathrm{dr})$

$\mathrm{R}^{1}-\mathrm{R}^{2}=\left(\mathrm{CH}_{2}\right)_{4}, \mathrm{R}^{3}=\mathrm{OMe}, \mathrm{R}^{4}=\mathrm{H}, \mathrm{R}^{5}=p-(t-\mathrm{Bu})(56 \%)$

$\mathrm{R}^{1}-\mathrm{R}^{2}=\mathrm{OCH}_{2}, \mathrm{R}^{4}=\mathrm{H}, \mathrm{R}^{5}=p-(t-\mathrm{Bu}), \mathrm{R}^{3}=\mathrm{Me}(66 \%), i-\operatorname{Pr}(64 \%)$

$\mathrm{R}^{1}=\mathrm{Me}, \mathrm{R}^{2}=\mathrm{H}, \mathrm{R}^{3}=\mathrm{OEt}, \mathrm{R}^{4}=\mathrm{H}, \mathrm{R}^{5}=p-(t-\mathrm{Bu})(55 \%)$ 


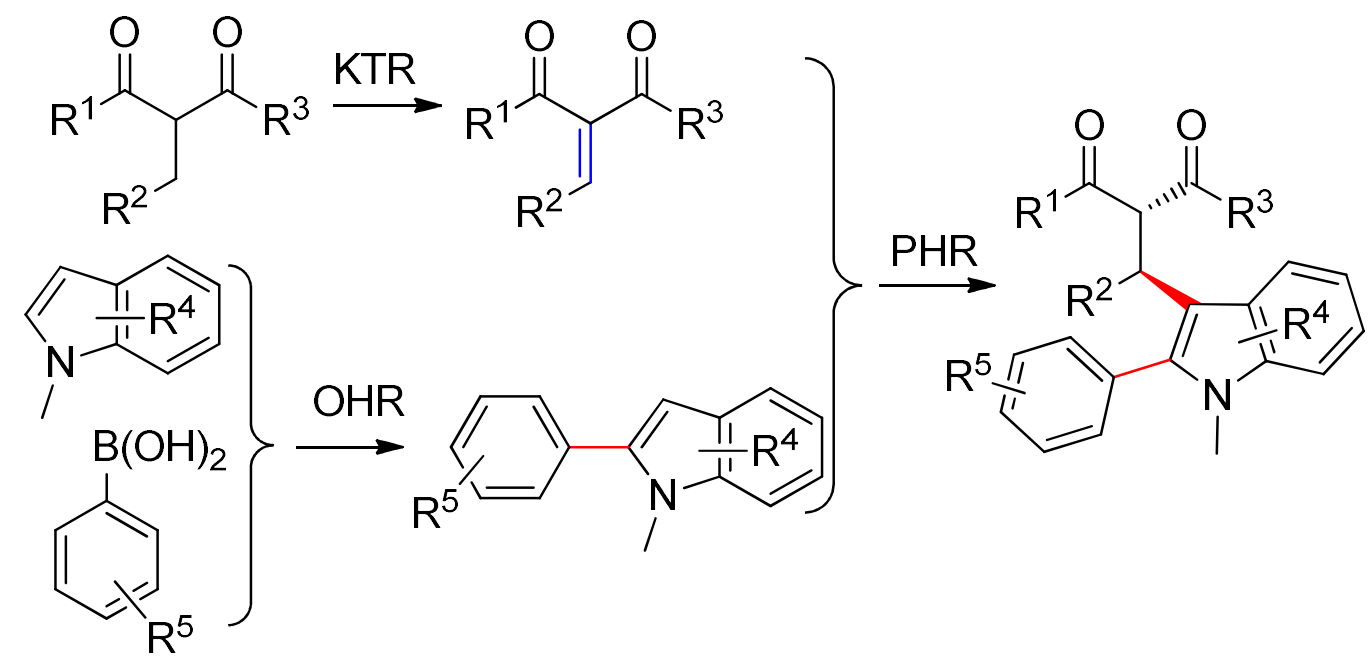

Scheme 9. Successive steps of Pihko's three-component domino reactions.

\section{Domino HR + KTR (+ HR)}

While Heck reaction between phenyl iodide and allyl alcohol led, in most cases, to a mixture of 3- and 2-phenylpropanal, the linear isomer being the major product, ${ }^{[75]} \mathrm{Wang}, \mathrm{Li}$ and coworkers, in 2010, succeeded domino (HR-KTR)s leading to cinnamaldehydes with high selectivities from such substrates [Eq. (37)]. ${ }^{[76]}$ The reactions were carried out in the presence of catalytic $\mathrm{Pd}(\mathrm{OAc})_{2}, \mathrm{Bu}_{4} \mathrm{NCl}$ and $\mathrm{NaHCO}_{3}$ in $\mathrm{DMSO} / \mathrm{DMF}$ with oxygen to regenerate the $\mathrm{Pd}^{\mathrm{II}}$ species required for the dehydrogenation (Scheme 10). ${ }^{[38]}$ The HR leads to arylated enolic species $10 \mathrm{~A}$, which coordinates to $\mathrm{Pd}(\mathrm{OAc})_{2}$ to finally afford the product.

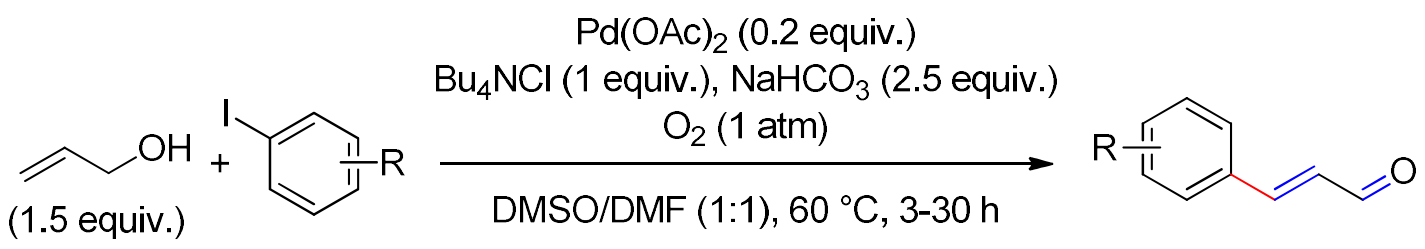

$$
\begin{aligned}
\mathrm{R}= & \mathrm{H}\left(79 \%^{\mathrm{a}}\right), \mathrm{o}-\mathrm{Me}(81 \%), \mathrm{o}-\mathrm{Cl}(81 \%), o-\mathrm{CO}_{2} \mathrm{Me}(80 \%), m-\mathrm{Me}(78 \%), m-\mathrm{F}(59 \%), p-\mathrm{Me}(81 \%), \\
& p-\mathrm{Et}(72 \%), p-\mathrm{CN}\left(68 \%{ }^{\mathrm{a}}\right), p-\mathrm{NO}_{2}\left(60 \%{ }^{\mathrm{a}}\right), p-\mathrm{Cl}(62 \%), p-\mathrm{Ac}(67 \%), p-\mathrm{CO}_{2} \mathrm{Me}(80 \%), p-\mathrm{Ph}(80 \%)
\end{aligned}
$$

aplus $\operatorname{Ar}\left(\mathrm{CH}_{2}\right)_{2} \mathrm{CHO}(1-5 \%)$ 


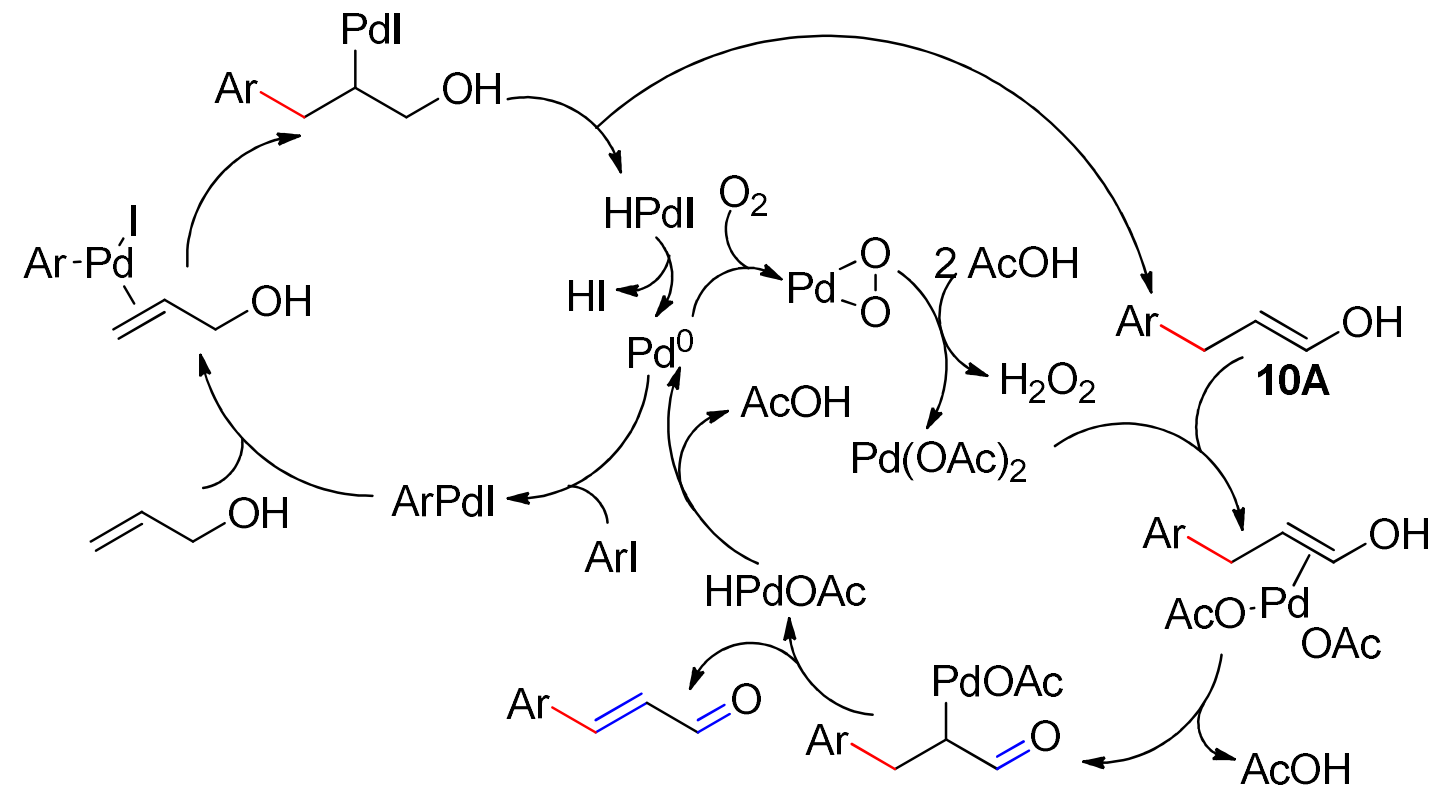

Scheme 10. Synthesis of enals from aryl iodides and allyl alcohol.

While the above (HR-KTR)s were carried out with an excess of allyl alcohol versus ArI, Huang and co-workers used an excess of the latter. Thus, they synthetized 3,3-diaryl propenals by triple palladium catalysis. ${ }^{[77]}$ The cross-coupling product issued of the HR-KTR undergoes, in-situ, a Heck reaction leading to the HR-KTR-HR compound [Eq. (38)].

Subjecting 3-iodothiophene to similar experimental conditions afforded 3,3-di(thiophen-3yl)acrylaldehyde in a modest yield [Eq. (39)].

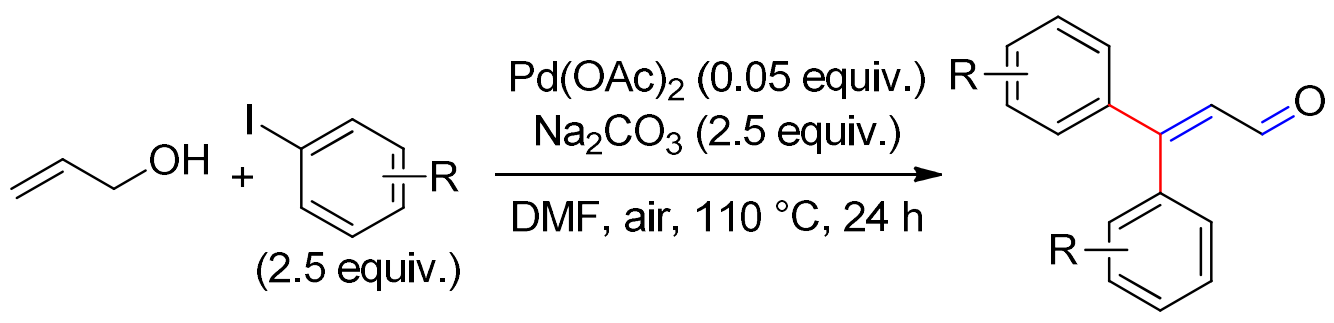

$\mathrm{R}=\mathrm{H}(64 \%)^{\mathrm{a}}, m-\mathrm{MeO}(60 \%), p-\mathrm{Me}(67 \%), p-\mathrm{Et}(67 \%), p-(\mathrm{t}-\mathrm{Bu})(68 \%)$, $p-\mathrm{MeO}(66 \%), p-\mathrm{F}(43 \%), p-\mathrm{Cl}(51 \%)$

aOther catalysts: $\mathrm{PdCl}_{2}(37 \%), \mathrm{Pd}\left(\mathrm{PPh}_{3}\right)_{4}(35 \%), \mathrm{Pd}(\mathrm{dba})_{3}(43 \%)$.

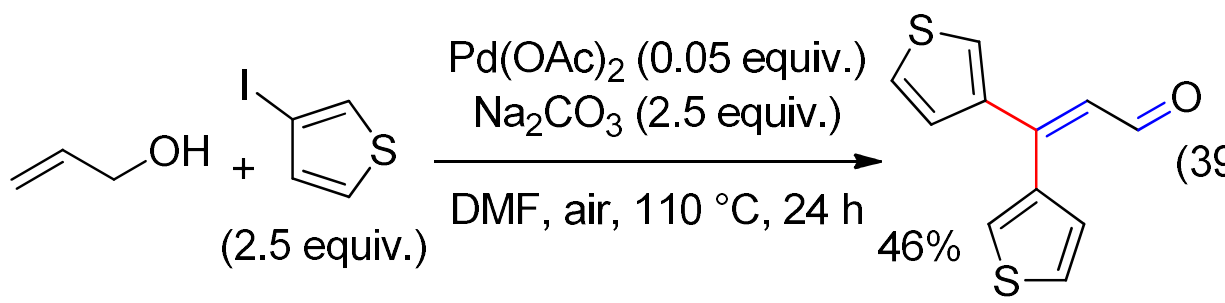

\section{Domino KTR + ketonisation + DHR}

Tetracyclic compounds have been prepared by Hong's team from the domino reaction of 2benzylchroman-4-ones and 2-benzyl-2,3-dihydroquinolin-4(1H)-ones [Eq. (40)]. ${ }^{[55]}$ These syntheses involve three steps: i) the KTR, ii) the benzylic oxidation and iii) the DHR. Control experiments showed that the benzylic oxidation is mediated by $\mathrm{Cu}(\mathrm{OAc})_{2} / \mathrm{O}_{2}$. The procedure 
allowed the synthesis of Wrightiadione $\left(\mathrm{Z}=\mathrm{O}, \mathrm{R}^{1}=\mathrm{R}^{2}=\mathrm{H}\right)$, which is a natural product exhibiting a broad range of biological activities.

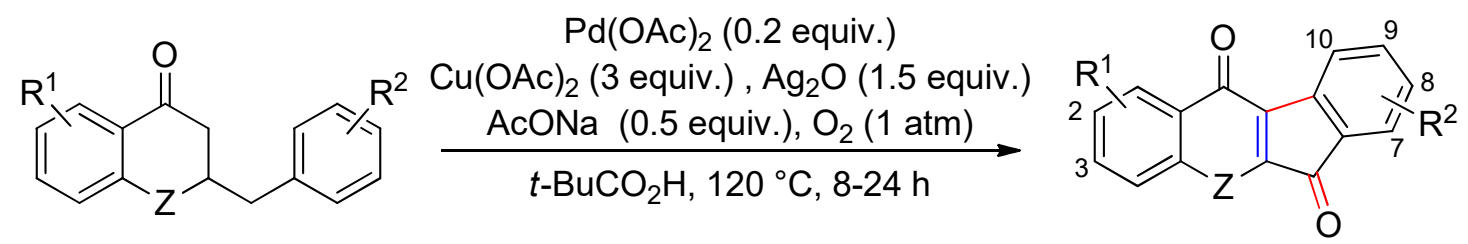

$Z=\mathrm{NMe}, \mathrm{R}^{1}=\mathrm{H}, \mathrm{R}^{2}=\mathrm{H}\left(67 \%^{\mathrm{a}}, 74 \%^{\mathrm{b}}\right), 7-\mathrm{OH}(33 \%), 9-\mathrm{Me}(63 \%), 9-(t-\mathrm{Bu})(59 \%), 9-\mathrm{OMe}(63 \%)$, $8-\mathrm{Me}+10-\mathrm{Me}(57 \%, 4.7: 1), 8-\mathrm{OMe}+10-\mathrm{OMe}(62 \%, 5: 1)$

$\mathrm{Z}=\mathrm{NMe}, \mathrm{R}^{2}=\mathrm{H}, \mathrm{R}^{1}=2-\mathrm{Me}(71 \%), 3-\mathrm{CF}_{3}(67 \%), 3-\mathrm{OMe}(62 \%), 3-\mathrm{Cl}(63 \%)$

$\mathrm{R}^{1}=\mathrm{H}, \mathrm{R}^{2}=\mathrm{H}, \mathrm{Z}=\mathrm{NPh}\left(55^{\mathrm{c}}\right), \mathrm{NBn}\left(66 \%{ }^{\mathrm{c}}\right), \mathrm{NCO}_{2} \mathrm{Et}(60 \%)$

$Z=O, R^{1}=H, R^{2}=H(52 \%), 7-M e(34 \%), 9-O M e(42 \%), 8-M e+10-M e(37 \%, 5.3: 1)$

$\mathrm{Z}=\mathrm{O}, \mathrm{R}^{2}=\mathrm{H}, \mathrm{R}^{1}=2-\mathrm{F}(40 \%)$

a 2-benzoyl-1-methylquinolin-4(1H)-one (11\%) as by-product.

${ }^{b} t-B_{1} C_{2} \mathrm{H} / t-B u O A c(10: 1)$ as the solvent, 2-benzoyl-1-methylquinolin-4(1H)-one (9\%) as by-product. ${ }^{c} t-\mathrm{BuCO}_{2} \mathrm{H} / t-\mathrm{BuOAc}(10: 1)$ as the solvent.

\section{Domino C(sp $\left.{ }^{3}\right)-H$ arylation + KTR + HR (+ DHR)}

In 2001, Miura and co-workers reported the first domino reaction related to the topic of the review. Three Pd-catalyzed reactions of propiophenone were involved, $\alpha$-phenylation, dehydrogenation and Heck reaction, which successively arose in a basic media at $160{ }^{\circ} \mathrm{C}$ with $\mathrm{Pd}(\mathrm{OAc})_{2} / \mathrm{PPh}_{3}$ as the catalytic system [Eq. (41)]. ${ }^{[78]}$ The first step of the process is well known with reports from the Miura, Buchwald and Hartwig teams. ${ }^{[79,80]}$ Mechanistically, the $\alpha$-phenylation occurs through a phenylpalladium enolate, which provides the $\alpha$-phenylated product upon reductive elimination.

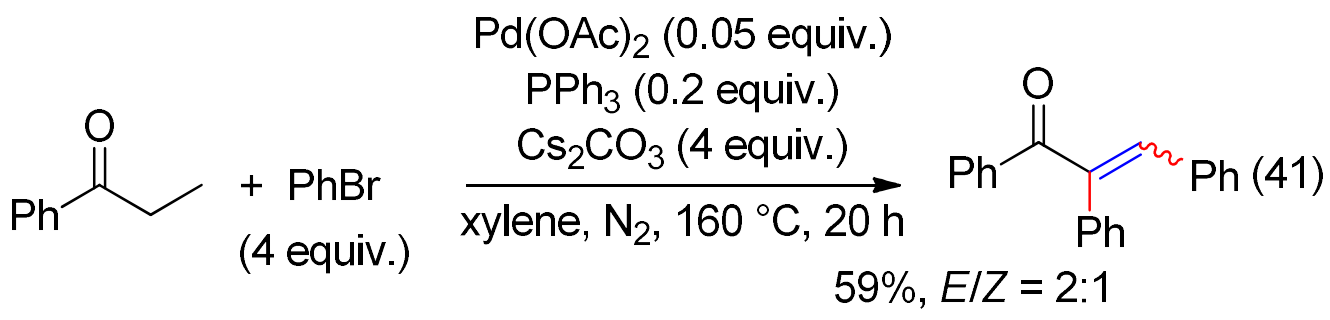

An extensive domino reaction arose from butyrophenone leading to the formation of up to five C-C bonds [Eq. (42)]. ${ }^{[78]}$ The successive steps, which require either $\mathrm{Pd}^{0}$ or $\mathrm{Pd}^{\mathrm{II}}$ catalyst, are proposed in Scheme 11. Under the reaction conditions, triphenylphosphine may mediate the reduction of $\mathrm{Pd}(\mathrm{OAc})_{2},{ }^{[81]}$ while $\mathrm{PhBr}$ forms active $\mathrm{Pd}^{\mathrm{II}}$ species from $\mathrm{Pd}^{0} .{ }^{[31]}$ The first reaction of butyrophenone would be either the dehydrogenation or the $\alpha$-phenylation leading to $[11 \mathrm{~A}]$ or $11 \mathrm{~B}$, respectively. The triphenylation product $11 \mathrm{C}$ is issued either from [11A] or via the dehydrogenation product [11D] of 11B. Both pathways involve double bond isomerization and multiple Heck reactions, the isomerization being probably $\mathrm{Pd}^{\mathrm{II}}$-catalyzed ${ }^{[82]}$ but, given the reaction temperature, $\mathrm{Pd}^{0}$ species could also be involved. ${ }^{\left[{ }^{[3]}\right.} \mathrm{HR}$ of $11 \mathrm{C}$ affords 11E, which may suffer $\mathrm{Pd}^{0}$-catalyzed ortho-phenylation of the benzoyl group ${ }^{[84]}$ to deliver 11F. Another plausible pathway for the latter is ortho-phenylation of 11C leading to [11G], followed by HR. Triphenylnaphthalenone $\mathbf{1 1 H}$ could be obtained from intramolecular DHR 
of 11C. ${ }^{[85]}$ The process was extended to other substrates but only the main products were characterized [Eq. (43)].<smiles>CCC(C(=O)c1ccccc1)c1ccccc1C(=O)C(C=C(c1ccccc1)c1ccccc1)C(=O)c1ccccc1-c1ccccc1</smiles>

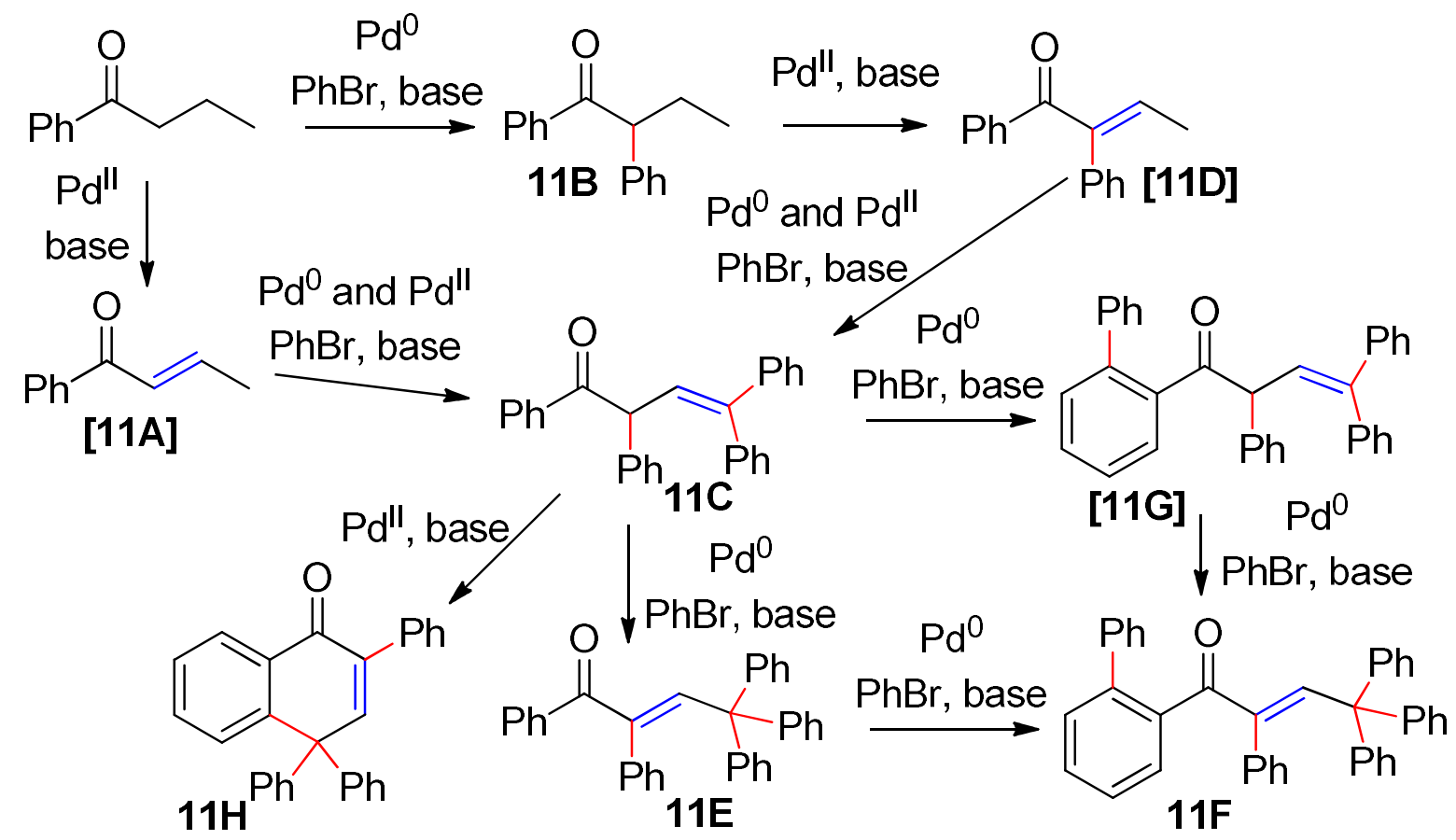

Scheme 11. Domino reaction of butyrophenone. The numbers in square brackets correspond to suspected intermediates.<smiles>[R]c1ccc(C(=O)c2cc([R])ccc2C(=O)/C(=C/C(c2ccc([R])cc2)(c2ccc([R])cc2)c2ccc([R])cc2)c2ccc([R])cc2)cc1</smiles> 


\section{Domino C(sp $\left.{ }^{3}\right)-H$ arylation + KTR $($ or KTR $+H R)+H R+C\left(s^{2}\right)-H$ amidation}

Preparation of 4-aryl-2-quinolinones from the treatment in $t$-amyl alcohol of $N$ - $(2,3,5,6$ tetrafluoro-4-(trifluoromethyl)phenyl)propionamides with aryl iodides, silver carbonate and catalytic amounts of both $\mathrm{PdCl}_{2}$ and 2.5-lutidine was discovered by $\mathrm{Yu}$ 's team [Eq. (44)]. ${ }^{[86]}$ The efficiency highly depends on both ligand and $N$-aryl group. Indeed, the process stopped at the level of the first arylation in the absence of lutidine, or led to lower yields with other $\mathrm{N}$ aryl groups [Eq. (44)].<smiles>[R]c1ccc(I)cc1</smiles>

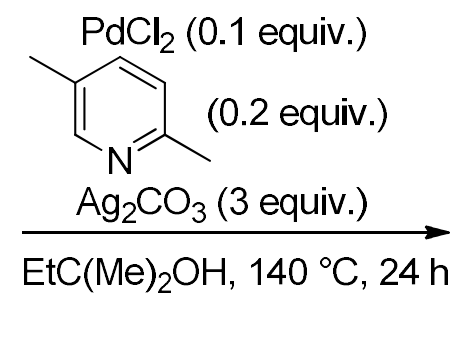

$\mathrm{R}=\mathrm{H}(80 \%)^{\mathrm{a}, \mathrm{b}, \mathrm{c}}, m$-Me $(71 \%), p-\mathrm{Me}(75 \%), p-\mathrm{OMe}(60 \%)$, $p-\mathrm{F}(60 \%), p-\mathrm{Cl}(63 \%), p-\mathrm{CF}_{3}(75 \%), p-\mathrm{CO}_{2} \mathrm{Me}(44 \%)$ ${ }^{a} 68 \%$ with pyridine instead of 2,5 -lutidine and formation of $A(23 \%)$. ${ }^{\mathrm{b}} 0 \%$ in the absence of 2,5 -lutidine and formation of $\mathbf{A}(11 \%)$. ${ }^{\mathrm{c}} 48 \%$ using $N$-phenylpropionamide as the substrate.<smiles>[R]c1ccccc1-c1cc(=O)n(-c2c(F)c(F)c(C(F)(F)F)c(F)c2F)c2ccccc12</smiles>

The authors considered that these domino reactions involve a triple $\mathrm{C}-\mathrm{H}$ activation, and proposed the $\mathrm{C}\left(\mathrm{sp}^{3}\right)-\mathrm{H}$ arylation of the amide followed by a KTR leading to intermediate 12A (Scheme 12, path $a$ ). This arylation regioselectivity contrasts with that of propiophenone [Eq. (41)]. The amide group could favor the $\beta-\mathrm{C}\left(\mathrm{sp}^{3}\right)$-H activation, but the mechanism studies of the arylation of ester enolates summarized in Sub-chapter 6.1 (Scheme 6) ${ }^{[69]}$ leads us to suspect a KTR-HR as another plausible pathway (Scheme 12, path $b$ ). HR of 12A affords 12B via syn insertion of $\mathrm{C}=\mathrm{C}$ bond into the $\mathrm{Ar}^{2}-\mathrm{PdI}$ bond, rotation around the $\mathrm{C}-\mathrm{C}$ bond and $\operatorname{syn} \beta$ $\mathrm{H}$ elimination. ${ }^{[87]}$ Subsequent intramolecular $\mathrm{C}-\mathrm{N}$ bond formation by $\mathrm{Pd}^{\mathrm{II}}$-catalyzed dehydrogenative coupling gives 12C. ${ }^{[88,89]}$ The proposed 12A to 12B pathway is consistent with the arylation of $\beta$-substituted propionamides depicted in Eq. (45). Indeed, this stereospecific domino reaction would occur via KTR-HR and then dehydrogenative cyclization rather than $\mathrm{C}\left(\mathrm{sp}^{3}\right)-\mathrm{H}$ arylation followed by KTR and subsequent dehydrogenative cyclization. 


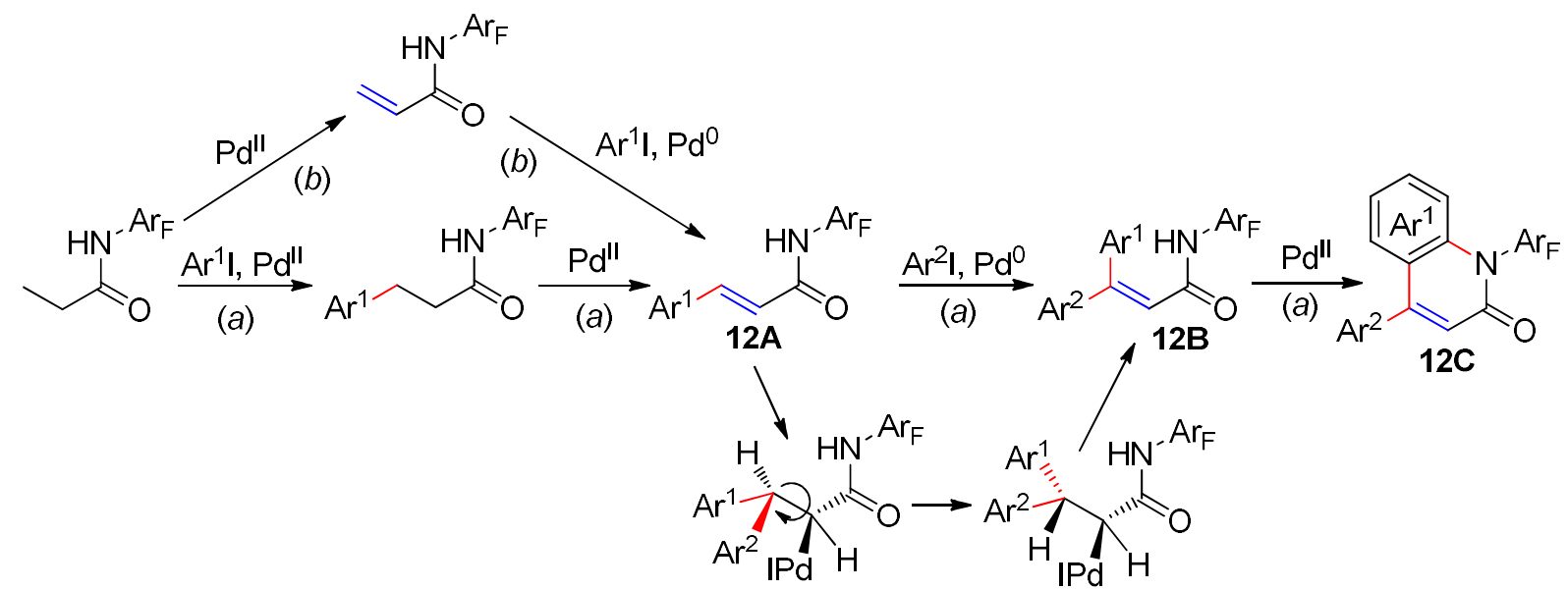

Scheme 12. Plausible catalytic pathways leading to 2-quinolinones from propionamides.

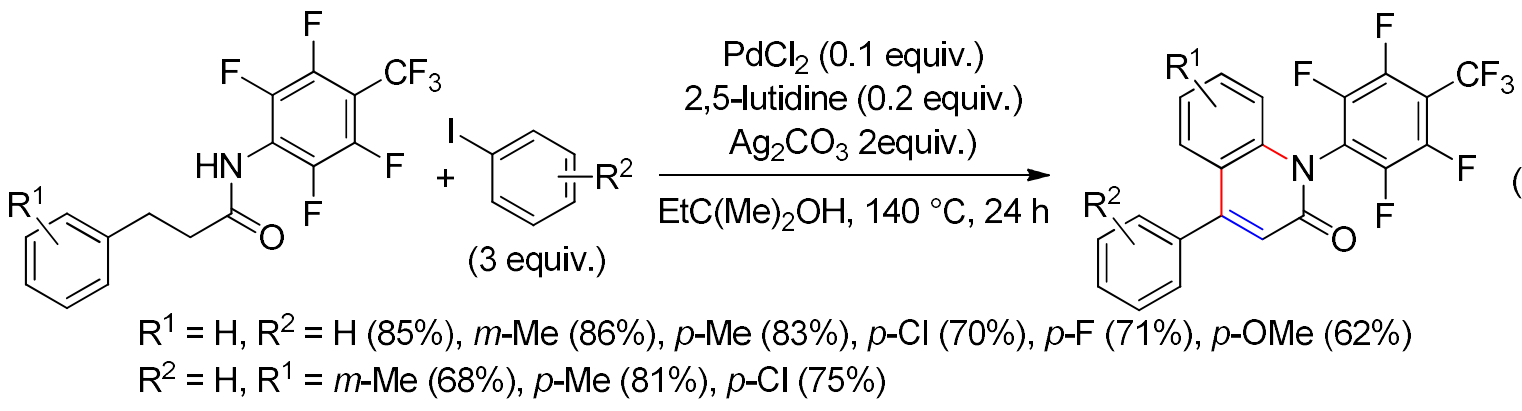

\section{Conclusion}

The Pd-catalyzed domino dehydrogenation/enone functionalization are often included in domino multi-reactions, thus in processes with increased values. Indeed, the green and economic interests of a domino reaction is correlated with the number of bonds efficiently created during the process. Most domino reactions above highlighted occur under routine laboratory conditions and are not limited to a few examples. Moreover, some of them are carried out under enantio- or diasteroselective conditions, or afford products with structural complexity. Thus, these domino reactions belong to the toolbox of synthetic organic chemists. The mechanism of the different steps is often attributed with good confidence but a few remain matter of debate. It is plausible that other functionalizations ascribed, in the literature, to a $\beta-\mathrm{C}\left(\mathrm{sp}^{3}\right)-\mathrm{H}$ activation could, in fact, arise through a dehydrogenation pathway.

\section{References}

(1) For recent one-pot Pd-catalyzed reactions, see: a) N. Rana, P. Niharika, D. R. Kishore, G. Satyanarayana, ChemistrySelect 2017, 2, 10809-10813; b) K. M. Saini, R. K. Saunthwala, A. K. Verma, Org. Biomol. Chem. 2017, 15, 10289-10298; d) A.D. Manick, F. Berhal, G. Prestat, Org. Lett. 2018, 20, 194-197; e) A. Soozani, A. Keivanloo, M. Bakherad, Tetrahedron 2018, 74, 150-156; f) S. Basuli, G. Satyanarayana, Eur. J. Org. Chem. 2018 In press.

(2) L. F. Tietze, Chem. Rev. 1996, 96, 115-136.

(3) According to Tietze, ${ }^{2}$ the expression cascade is less appropriated than domino for these reactions.

(4) D. E. Fogg, E. N. dos Santos, Coord. Chem. Rev. 2004, 248, 2365-2379. 
See Ref. 3 in $^{2}$.

A few examples are included in other reviews: a) S. S. Stahl, T. Diao, In Comprehensive Organic Synthesis G. A. Molander, P. Knochel, Eds, 2nd Edition, Vol. 7, Elsevier, Oxford, 2014, pp 178-212; b) Z. Chen, B. Wang, J. Zhang, W. Yu, Z. Liu, Y. Zhang, Org. Chem. Front. 2015, 2, 1107-1295.

a) J. E. Camp, Eur. J. Org. Chem. 2017, 425-433; b) N. Shindoh, Y. Takemoto, K. Takasu, Chem. Eur. J. 2009, 15, 12168-12179.

For such one-pot reactions relevant to the topic of the review, see: a) D. Kim, M. Min, S. Hong, Chem. Commun. 2013, 49, 4021-4023; b) Y. Izawa, C. Zheng, S. S. Stahl, Angew. Chem. Int. Ed. 2013, 52, 3672-3675; c) J. H. Park, C. Y. Park, M. J. Kim, M. U. Kim, Y. J. Kim, G.-H. Kim, C. P. Park, Org. Process Res. Dev. 2015, 19, 812-818.

J. Muzart, Eur. J. Org. Chem. 2010, 3779-3790.

a) H. Baltz, B. Bierling, K. Kirschke, H. Oberender, M. Schulz, Ger. Offen. DE 2050566, 1971; Chem. Abstr. 75, 19706; b) H. Baltz, B. Bierling, K. Kirschke, H. Oberender, M. Schulz, Brit. Pat. Appl. GB 71-3490 19710129, 1973; Chem. Abstr. 80, 120393; c) K. Kirschke, H. W. Krause, H. Mennenga, D. Timm, Ger. (East) GEXXA8 DD 107253, 1974; Chem. Abstr. 83, 9291.

R. J. Theisen, J. Org. Chem. 1971, 36, 752-757.

J. Muzart, J.-P. Pète, J. Mol. Catal. 1982, 15, 373-376.

Y. Ito, T. Hirato, T. Saegusa, J. Org. Chem. 1978, 43, 1011-1013.

For reviews, see: a) Y. Ito, M. Suginome, In Handbook of Organopalladium Chemistry for Organic Synthesis, Wiley, Hoboken, 2002, pp 2873-2879; b) J. Le Bras, J. Muzart, Org. React. In press.

A. V. Iosub, S. S. Stahl, ACS Catal. 2016, 6, 8201-8213.

a) The Mizoroki-Heck Reaction M. Oestreich, Ed., Wiley: Chichester, 2009; b)

Science of Synthesis: Cross Coupling and Heck-type Reactions 3, M. Larhed, Ed.

Georg Thieme Verlag: Stuttgart; 2013; c) S. Jagtap, Catalysts 2017, 7, 267 (53 pages)

J. Muzart, Tetrahedron 2013, 69, 6735-6785.

T. Mizoroki, K. Mori, A. Ozaki, Bull. Chem. Soc. Jpn. 1971, 44, 581-581; submitted on October, 20, 1970.

a) M. Julia, M. Duteil "Pli cacheté", that is, a sealed envelope, deposited to the Société Chimique de France on January 12, 1971; b) M. Julia, M. Duteil, Bull. Soc. Chim. Fr. 1973, 2790.

R. F. Heck, J. P. Nolley, Jr. J. Org. Chem. 1972, 37, 2320-2322; submitted on January, 13, 1972.

a) R. F. Heck, J. Am. Chem. Soc. 1968, 90, 5518-5526; b) R. F. Heck, J. Am. Chem. Soc. 1969, 91, 6707-6714; c) P.-A. Enquist, P. Nilsson, P. Sjöberg, M. Larhed, J. Org. Chem. 2006, 71, 8779-8786.

a) K. M. Gligorich, M. S. Sigman, Chem. Commun. 2009, 3854-3867; b) Y. Su, N. Jiao, Curr. Org. Chem. 2011, 15, 3362-3388. 
(23) a) A. G. Myers, D. Tanaka, M. R. Mannion, J. Am. Chem. Soc. 2002, 124, 1125011251; b) D. Tanaka, S. P. Romeril, A. G. Myers, J. Am. Chem. Soc. 2005, 127, 10323-10333; c) D. Tanaka, A. G. Myers, Org. Lett. 2004, 6, 433-436.

(24) a) I. Moritani, Y. Fujiwara, Tetrahedron Lett. 1967, 1119-1122; b) Y. Fujiwara, I. Moritani, M. Matsuda, S. Teranishi, Tetrahedron Lett. 1968, 3863-3865.

(25) a) J. Le Bras, J. Muzart, Chem. Rev. 2011, 111, 1170-12140; b) P. K. Dornan, V. M. Dong In Science of Synthesis: Catalytic Transformations via C-H Activation, Vol 1, J.-Q. Yu, Ed. Georg Thieme Verlag: Stuttgart; 2016, pp 155-196.

(26) a) G. E. Stokker, Tetrahedron Lett. 1987, 28, 3179-3182; b) S. Cacchi, Pure Appl. Chem. 1990, 62, 713-722; c) S. Mannathan, S. Raoufmoghaddam, J. N. H. Reek, J. G. de Vries, A. J. Minnaard, ChemCatChem 2015, 7, 3923-3927 (corrigendum 2016, 8, 2572).

(27) S. Raoufmoghaddam, S. Mannathan, A. J. Minnaard, J. G. de Vries, B. de Bruin, J N. H. Reek, ChemCatChem 2018, 10, 266-272.

(28) Z. Huang, G. Dong, J. Am. Chem. Soc. 2013, 135, 17747-17750.

(29) M. V. Leskinen, Á. Madarász, K.-T. Yip, A. Vuorinen, I. Pápai, A. J. Neuvonen, P. M. Pihko, J. Am. Chem. Soc. 2014, 136, 6453-6462.

(30) P. Gandeepan, P. Rajamalli, C.-H. Cheng, ACS Catal. 2014, 4, 4485-4489.

(31) a) Y.Tamaru, Y. Yamamoto, Y. Yamada, Z. Yoshida, Tetrahedron Lett. 1979, 1401-1404; b) J. Muzart, Tetrahedron 2003, 59, 5789-5816 and cited references.

(32) KTR of pentanal has been reported: Y. Shvo, A. H. I. Arisha, J. Org. Chem. 1998, 63, 5640-5642.

(33) HR of crotonaldehyde and RHR of hept-3-en-2-one have been reported: M. Stadler, B. List, Synlett 2008, 597-599 and N. Parveen, R. Saha, G. Sekara, Adv. Synth. Catal. 2017, 359, 3741-3751, respectively.

(34) The reaction of propiophenone $(0.5 \mathrm{mmol})$ with 4-bromotoluene was carried out in the presence of dppb (0.012 equiv.). Personal communication from Professor C.-H. Cheng, January, 6, 2018.

(35) For Pd ${ }^{\mathrm{II}} / \mathrm{DMSO}$ complexes, see: a) A. I. Stash, T. I. Perepelkova, S. V. Kravtsova, Yu. G. Noskov, I. P. Romm, Koord. Khim. 1998, 24, 40-43, Translation: Russ. J. Coord. Chem. 1998, 24, 36-39; b) W. Zierkiewicz, T. Privalov, Organometallics 2005, 24, 6019-6028.

(36) L. Xiao, Y. Zheng, Q. Xie, L. Shao, Eur. J. Org. Chem. 2017, 5880-5883.

(37) $\mathrm{Ag}_{2} \mathrm{CO}_{3}$ can be both base and oxidant. For its use to regenerate $\mathrm{Pd}^{\mathrm{II}}$-active species, see: a) S. H. Cho, S. J. Hwang, S. Chang, J. Am. Chem. Soc. 2008, 130, 92549256, b) Y. Yang, K. Cheng, Y. Zhang, Org. Lett. 2009, 11, 5606-5609; c) X. Zhang, S. Fan, C.-Y. He, X. Wan, Q.-Q. Min, J. Yang, Z.-X. Jiang, J. Am. Chem. Soc. 2010, 132, 4506-4507. For the multiple roles of silver salts in palladiumcatalyzed C-H activations, see: K. L. Bay, Y.-F. Yang, K. N. Houk, J. Organomet. Chem. 2018, In press.

(38) For reviews on the use of $\mathrm{O}_{2}$ to regenerate $\mathrm{Pd}^{\mathrm{II}}$-active species, see: a) K. M. Gligorich, M. S. Sigman, Angew. Chem. Int. Ed. 2006, 45, 6612-6615; b) J. Muzart, Chem. Asian J. 2006, 1, 508-515; c) K. M. Gligorich, M. S. Sigman, 
Chem. Commun. 2009, 3854-3867; d) M. L. Scheuermann, K. I. Goldberg, Chem. Eur. J. 2014, 20, 14556-14568.

(39) J. Lee, J. Yu, S. H. Son, J. Heo, T. Kim, J.-Y. An, K.-S. Inn, N.-J. Kim Org. Biomol. Chem. 2016, 14, 777-784.

(40) a) R. C. Larock, T. R. Hightower, J. Org. Chem. 1993, 58, 5298-5300; b) J. Muzart, In Comprehensive Organic Synthesis G. A. Molander, P. Knochel, Eds, 2nd Edition, Vol. 7, Oxford: Elsevier, 2014, pp 295-301.

(41) C. J. C. Lamb, B. G. Nderitu, G. McMurdo, J. M. Tobin, F. Vilela, A.-L. Lee, Chem. Eur. J. 2017, 23, 18282-18288.

(42) A. J. J. Lennox, G. C. Lloyd-Jones, Chem. Soc. Rev. 2014, 43, 412-443.

(43) J. Zhou, G. Wu, M. Zhang, X. Jie, W. Su, Chem. Eur. J. 2012, 18, 8032-8036.

(44) J. L. Rutherford, M. P. Rainka, S. Buchwald, J. Am. Chem. Soc. 2002, 124, 1516815169.

(45) Y. Moon, D. Kwon, S. Hong, Angew. Chem. Int. Ed. 2012, 51, 11333-11336.

(46) As for the alkenylation of chromones, ${ }^{47}$ trace of the C3-product was detected.

(47) a) K. H. Kim, H. S. Lee, S. H. Kim, J. N. Kim, Tetrahedron Lett. 2012, 53, 27612764; b) M. Min, H. Choe, S. Hong, Asian J. Org. Chem. 2012, 1, 47-50.

(48) D. Kim, S. Hong, Org. Lett. 2011, 13, 4466-4469.

(49) S. Chen, X. Chang, Y. Tao, H. Chena, Y. Xiaa, Org. Biomol. Chem. 2015, 13, 10675-10680.

(50) M. Li, L. Li, H. Ge, Adv. Synth. Catal. 2010, 352, 2445-2449.

(51) Y.-Y. Yu, G. I. Georg, Adv. Synth. Catal. 2014, 356, 1359-1369.

(52) Y.-Y. Yu, G. I. Georg, Chem. Commun. 2013, 49, 3694-3696.

(53) F. Chen, Z. Feng, C.-Y. He, H.-Y. Wang, Y.-I. Guo, X. Zhang, Org. Lett. 2012, 14, 1176-1179.

(54) F. Jafarpour, H. Hazrati, N. Mohasselyazdi, M. Khoobi, A. Shafiee, Chem. Commun. 2013, 49, 10935-10937.

(55) Y. Jeong, Y. Moon, S. Hong, Org. Lett. 2015, 17, 3252-3255.

(56) J. Tsuji, Palladium Reagents and Catalysts, Innovations in Organic Synthesis, Wiley: Chichester, UK, 1995, p. 127.

(57) J. P. Knowles, A. Whiting, Org. Biomol. Chem. 2007, 5, 31-44.

(58) R. Imbos, A. J. Minnaard, B. L. Feringa, Dalton Trans. 2003, 2017-2023.

(59) M. Lautens, Y. Q. Fang, Org. Lett. 2003, 5, 3679-3682.

(60) M. Ikeda, S. A. A. El Bialy, T. Yakura, Heterocycles 1999, 51, 1957-1970.

(61) A radical Heck process has been suggested in the case of formal $\beta$-H antielimination: S. A. Ahmad-Junan, P. C. Amos, D. A. Whiting, J. Chem. Soc., Perkin Trans. I 1992, 539-545.

(62) a) T. Vogler, A. Studer, Org. Lett. 2008, 10, 129-131; b) S. Kirchberg, R. Fröhlich, A. Studer, Angew. Chem. Int. Ed. 2009, 48, 4235-4238.

(63) TEMPO (2,2,6,6-tetramethyl piperidine- $N$-oxyl) has been already associated to $\mathrm{Ag}_{2} \mathrm{CO}_{3}$ for Pd ${ }^{\mathrm{II}}$-catalyzed reactions of C-H bonds: E. J. Yoo, M. Wasa, J.-Q. Yu, J. Am. Chem. Soc. 2010, 132, 17378-17380.

(64) Y. Shang, X. Jie, J. Zhou, P. Hu, S. Huang, W. Su, Angew. Chem. Int. Ed. 2013, 52, 1299-1303. 
N. Gigant, J.-E. Bäckvall, Chem. Eur. J. 2014, 20, 5890-5894.

J. Piera, J.-E. Bäckvall, Angew. Chem. Int. Ed. 2008, 47, 3506-3523.

M. Jørgensen, S. Lee, X. Liu, J. P. Wolkowski, J. F. Hartwig, J. Am. Chem. Soc. 2002, 124, 12557-12565.

A. Renaudat, L. Jean-Gérard, R. Jazzar, C. E. Kefalidis, E. Clot, O. Baudoin, Angew. Chem., Int. Ed. 2010, 49, 7261-7265.

P. Larini, C. E. Kefalidis, R. Jazzar, A. Renaudat, E. Clot, O. Baudoin, Chem.

Eur. J. 2012, 18, 1932-1944.

For reviews highlighting some metal-catalyzed remote $\mathrm{C}\left(\mathrm{sp}^{3}\right)-\mathrm{H}$

functionalizations, see: a) R. Jazzar, J. Hitce, A. Renaudat, J. Sofack-Kreutzer, O.

Baudoin, Chem. Eur. J. 2010, 16, 2654-2672; b) K. M. Engle, T.-S. Mei, M.

Wasa, J.-Q. Yu, Acc. Chem. Res. 2012, 45, 788-802; c) N. Dastbaravardeh, M. Christakakou, M. Haider, M. Schnürch, Synthesis 2014, 46, 1421-1439; d) R. K. Rit, M. R. Yadav, K. Ghosh, A. K. Sahoo, Tetrahedron 2015, 71, 4450-4459; e) S. Moghimi, M. Mahdavi, A. Shafiee, A. Foroumadi, Eur. J. Org. Chem. 2016, 3282-3299; f) J. He, M. Wasa, K. S. L. Chan, Q. Shao, J.-Q. Yu, Chem. Rev. 2017, 117, 8754-8786; g) J. Le Bras, J. Muzart, Eur. J. Org. Chem. In press.

K.-T. Yip, R. Y. Nimje, M. V. Leskinen, P. M. Pihko, Chem. Eur. J. 2012, 18, 12590-12594.

M. V. Leskinen, K.-T. Yip, A. Valkonen, P. M. Pihko J. Am. Chem. Soc. 2012, 134, 5750-5753.

R. Y. Nimje, M. V. Leskinen, P. M. Pihko, Angew. Chem. Int. Ed. 2013, 52, 48184822.

Oxidative couplings between indoles at the 2-position and arylboronates or aryltrifluoroborates were previously reported: a) S.-D. Yang, C.-L. Sun, Z. Fang, B.-J. Li, Y.-Z. Li, Z.-J. Shi, Angew. Chem. Int. Ed. 2008, 47,1473-1476; b) J. Zhao, Y. Zhang, K. Cheng, J. Org. Chem. 2008, 73, 7428-7431; c) S. Kirchberg, R. Fröhlich, A. Studer, Angew. Chem. Int. Ed. 2009, 48, 4235-4238. For a review, see: P. Y. Choy, S. M. Wong, A. Kapdi, F. Y. Kwong, Org. Chem. Front. 2018, 5, 288321.

J. Muzart, Tetrahedron 2005, 61, 4179-4212.

J. Liu, J. Zhu, H. Jiang, W. Wang, J. Li, Chem. Commun. 2010, 415-417.

Z.-Q. Zhu, J.-S. He, H.-J. Wang, Z.-Z. Huang, J. Org. Chem. 2015, 80, 9354-9359. Y. Terao, Y. Kametai, H. Wakui, T. Satoh, M. Miura, M. Nomura, Tetrahedron 2001, 57, 5967-5974.

a) T. Satoh, Y. Kawamura, M. Miura, M. Nomura, Angew. Chem., Int. Ed. Engl. 1997, 36, 1740-1742; b) M. Palucki, S. L. Buchwald, J. Am. Chem. Soc. 1997, 119, 11108-1109; c) B. C. Hamann, J. F. Hartwig, J. Am. Chem. Soc. 1997, 119, $12382-$ 12283.

a) D. A. Culkin, J. F. Hartwig, Acc. Chem. Res. 2003, 36, 234-245; b) C. C. C. Johansson, T. J. Colacot, Angew. Chem., Int. Ed. 2010, 49, 676-707; c) F. Bellina, R. Rossi, Chem. Rev. 2010, 110, 1082-1146. 
(81) a) C. Amatore, A. Jutand, M. A. M'Barki, Organomet. 1992, 11, 3009-3013; b) C. Amatore, A. Jutand, Acc. Chem. Res. 2000, 33, 314-321; c) A. Bottoni, M. A. Carvajal, G. P. Miscione, J. J. Novoa, Molecular Physics 2010, 108, 1619-1640.

(82) A. Sen, T.-W. Lai, Inorg. Chem. 1984, 33, 3257-3258.

(83) a) H. A. J. Carless, D. J. Haywood, J. Chem. Soc., Chem. Commun 1980, 980981; b) Y. Hoshino, N. Takeno, Bull. Chem. Soc. Jpn 1994, 67, 2873-2875.

(84) D. Alberico, M. E. Scott, M. Lautens, Chem. Rev. 2007, 107, 174-238.

(85) Miura's team proposed different pathways for the production of $\mathbf{9 E}, \mathbf{9 F}$ and $\mathbf{9 I}{ }^{78}$

(86) Y. Deng, W. Gong, J. He, J.-Q. Yu, Angew. Chem. Int. Ed. 2014, 53, 6692-6695.

(87) R. Bernini, S. Cacchi, I. D. Salve, G. Fabrizi, Synlett 2006, 2947-2952.

(88) W. C. P. Tsang, N. Zheng, S. L. Buchwald, J. Am. Chem. Soc. 2005, 127, 1456014561.

(89) M.-L. Louillat, F. W. Patureau, Chem. Soc. Rev. 2014, 43, 901-910.

\section{Graphical abstract.}

Domino Reaction: start with all reagents and then, laisser-faire.

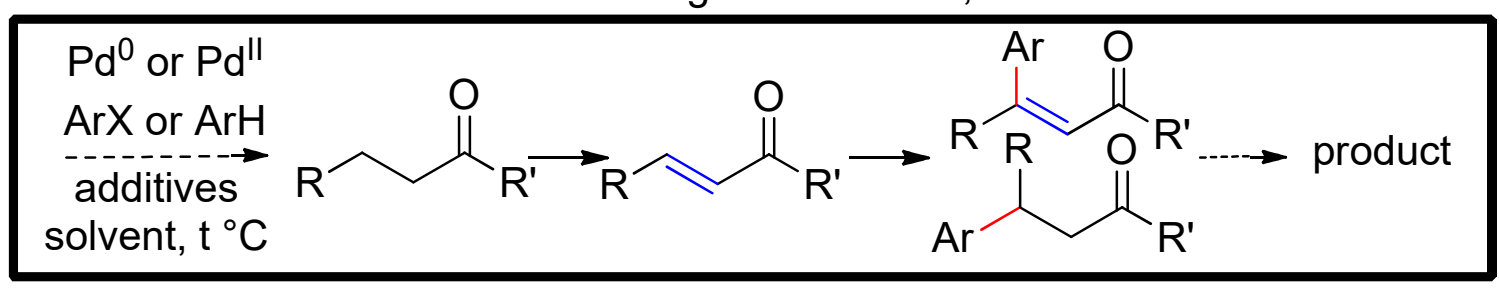

